\title{
Molecular and Chemical Analyses of Cyanobacterial Blooms in Tropical Lagoons from Southeast Brazil
}

\author{
Luciana Mecatti Elias' ${ }^{1}$, Maria Estela Silva-Stenico ${ }^{2}$, Danillo Oliveira Alvarenga², \\ Janaina Rigonato ${ }^{2}$, Marli Fátima Fiore ${ }^{2}$, Simone Possedente de Lira ${ }^{{ }^{*}}$ \\ ${ }^{1}$ Department of Exact Sciences, Escola Superior de Agricultura “Luiz de Queiroz", Universidade de São Paulo, \\ Piracicaba, Brazil \\ ${ }^{2}$ Centro de Energia Nuclear na Agricultura, Universidade de São Paulo, Piracicaba, Brazil \\ Email: splira@usp.br
}

Received 29 December 2014; accepted 18 January 2015; published 21 January 2015

Copyright (C) 2015 by authors and Scientific Research Publishing Inc.

This work is licensed under the Creative Commons Attribution International License (CC BY).

http://creativecommons.org/licenses/by/4.0/

(c) (7)

Open Access

\section{Abstract}

The genetic diversity and the potential toxicity of bloom-forming cyanobacteria were studied in four lagoons located in the state of São Paulo (Campinas, Limeira and Piracicaba cities). Bloom samples were collected on the water surface and cyanobacterial communities were evaluated using DGGE fingerprinting and $16 \mathrm{~S}$ rDNA clone library. The amplification of genes encoding secondary metabolites such as microcystin (mcy), anatoxin (ana), cylindrospermopsin (cyr), saxitoxin (sxt), cyanopeptolin ( $\mathrm{mcn}$ ) and aeruginosin (aer) was performed and their production analyzed by LC-MS. The comparison of DGGE banding pattern among the different water samples suggested that some operational taxonomic units (OTUs) in these locations were predominant over others. The 16S rDNA clone libraries sequences matched with nine different known cyanobacterial genera available in NCBI, identified as Anabaena, Brasilonema, Cylindrospermopsis, Limnococcus, Microcystis, Nostoc, Pseudanabaena, Synechococcus and Woronichinia. The lagoons ESALQ2, Taquaral and Limeira had more than $\mathbf{8 0 \%}$ of the cyanobacterial community assigned to the genus Microcystis. Genes encoding aeruginosin, cyanopeptolin and microcystin synthetases and saxitoxin synthase were amplified, and LC-MS/MS confirmed the production of aeruginosin, cyanopeptolin and microcystin. Rapid and sensitive methods for the detection of these secondary metabolites, especially toxins, using chemical and molecular tools together, can be used for a faster diagnostic of toxic cyanobacterial blooms.

\section{Keywords}

Cyanobacteria, Bloom, Cyanotoxins, Lagoons, Microcystis

\footnotetext{
${ }^{*}$ Corresponding author.
}

How to cite this paper: Elias, L.M., Silva-Stenico, M.E., Alvarenga, D.O., Rigonato, J., Fiore, M.F. and de Lira, S.P. (2015) Molecular and Chemical Analyses of Cyanobacterial Blooms in Tropical Lagoons from Southeast Brazil. Journal of Water Resource and Protection, 7, 50-71. http://dx.doi.org/10.4236/jwarp.2015.71004 


\section{Introduction}

Cyanobacterial blooms cause environmental, social and economic impacts, affecting both the aquatic and the terrestrial biomes. These bacteria release metabolites with toxic activity to animals and may change the water characteristics, such as increasing the turbidity, depleting the oxygen and producing unpleasant odour and taste [1] [2]. These cyclic peptides, alkaloids and lipopolysaccharides produced by cyanobacteria may cause hepatotoxic, neurotoxic and dermatotoxic effects in human health [3]-[5].

The methods for cyanotoxin detection are well established, including HPLC [6], mouse bioassays [7], mass spectrometry [8], protein phosphatase inhibition and ELISA assays [9], which are dependent on toxin production, and DNA based detection techniques [10] that are highly sensitive and able to determine the toxic potential even if the molecule is not being produced. The detection and analysis of the diversity of nucleic acids present in environmental samples is critical in studies of microbial diversity, mainly because such techniques allow the analysis of uncultured microorganisms, a fact which excludes major problems and limitations that occur due to low culturability of some communities.

Studies conducted in Brazil showed the occurrence of toxic blooms in several areas, with greater predominance of toxic blooms containing microcystin- and saxitoxin-producing cyanobacteria [11].

However, further studies are needed in recreational water reservoirs in detecting the presence of cyanobacteria and their toxins in these environments. The present study aimed to analyze, by culture-independent molecular techniques, samples of cyanobacteria found in four lagoons in São Paulo state, Brazil, both in an area of recreational purposes, and to detect the presence of toxins and protease inhibitors in water samples by mass spectrometry and PCR screening of their genes.

\section{Materials and Methods}

\subsection{Sites Descriptions and Sample Collection}

The four selected lagoons are public space for leisure and attract thousands of visitors weekly for recreational purposes. Visitors include families with children, cyclists, and animals, which can interact with these waters.

Bloom samples were collected from four different lagoons in São Paulo state, Brazil, during September 2010.

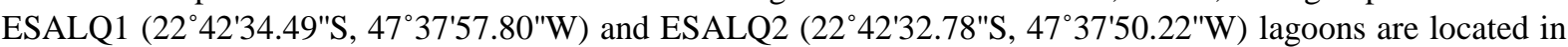
the University of São Paulo, Piracicaba, São Paulo state, Brazil, with $1.4 \mathrm{~m}$ average depth and $161.0 \mathrm{~m}^{2}$ surface area, and $2.0 \mathrm{~m}$ average depth and $1.5 \mathrm{~m}^{2}$ surface area, respectively. ESALQ1 contains a fountain, which provides water aeration. Taquaral lagoon ( $\left.22^{\circ} 52^{\prime} 25.2^{\prime \prime S}, 47^{\circ} 3^{\prime} 0.51^{\prime \prime W}\right)$ is located in Portugal Park, Campinas, São Paulo state, Brazil, with $2.8 \mathrm{~m}$ average depth and $146.5 \mathrm{~m}^{2}$ surface area. Limeira lagoon (22 30 '56.06"S, $\left.47^{\circ} 23^{\prime} 55.94^{\prime \prime} \mathrm{W}\right)$ is located in a sugarcane farm, Limeira, São Paulo state, Brazil, with 2.5 m average depth and $27.6 \mathrm{~m}^{2}$ surface area.

All samples were collected in triplicate using $4 \mathrm{~L}$ amber glass flasks close to the border of the lagoons at a depth of $0-20 \mathrm{~cm}$ and stored at $4^{\circ} \mathrm{C}$ for no longer than $24 \mathrm{~h}$. Afterwards, $1 \mathrm{~L}$ of each sample was concentrated by centrifugation at $13,000 \times \mathrm{g}$ for $15 \mathrm{~min}$. at $4^{\circ} \mathrm{C}$. The supernatant was removed and the pellet stored at $-20^{\circ} \mathrm{C}$. The pellet was dimidiate and used for the subsequent molecular and chemical analyses.

\subsection{DNA Extraction and PCR of the 16S rDNA}

Total DNA was extracted with MoBio PowerSoil DNA Isolation Kit (MoBio Laboratories) according to the manufacturer's instructions. The integrity and purity of the extracted DNA was verified by electrophoresis in 1\% agarose gel stained with SYBR Green I (Molecular Probes) using Low Mass DNA Ladder (Invitrogen) as molecular marker. The gel was photodocumented in a Kodak Gel Logic 212 Imaging System (Molecular Imaging System Carestream Health). Afterwards, PCR of the 16S rDNA was performed in a Techne TC-412 thermocycler (Bibby Scientific) with the primers 27F1 and 1494 Rc under previously described conditions [12].

\subsection{Denaturing Gradient Gel Electrophoresis (DGGE)}

The products of the 16S rDNA PCR were used as templates for a nested PCR with the primers CYA359F (with the addition of 40 bases GCclamp), CYA781Ra and CYA781Rb under previously described conditions [13], which was verified by electrophoresis in agarose as mentioned above. The resulting amplicons were separated 
by DGGE in $6 \%$ polyacrilamide gel with a denaturing gradient of urea and formamide varying from concentrations of $20 \%$ to $60 \%$ according to [14]. Electrophoresis of the polyacrilamide gel was performed in Ingeny phor $\mathrm{U} 2$ (Ingeny) at $60^{\circ} \mathrm{C}$ with a current of $100 \mathrm{~V}$. After a 15-hour run, the gel was silver-stained [15] and photodocumented.

\subsection{Clone Libraries}

The 16S rDNA amplicons from the environmental samples were used as templates for a nested PCR with the primers CYA359F (without a GCclamp), CYA781Ra and CYA781Rb as described above. The fragments amplified by the nested PCR were cloned with the pGEM-T Easy Vector kit (Promega) and used to transform One Shot TOP 10 Eletrocomp E. coli cells (Invitrogen) according to the manufacturer's instructions. Plasmids of successfully transformed cells were extracted by alkaline lysis [16], verified by PCR and sequenced with DYEnamic ET Terminator Cycle Sequencing Kit (GE Healthcare) in ABI PRISM 3100 Genetic Analyser (Applied Biosystems). The resulting sequences were trimmed to remove vector and sequences with bases of phred quality values lower than 20 using Geneious Pro 4.7.5 [17]. The sequences were aligned with ClustalW [18]. A similarity matrix was produced from the alignment by the DNADIST software [19] with the JukesCantor evolutionary model. The sequences were grouped into Operational Taxonomic Units (OTU) using the software DOTUR [20], in which they were binned using a cutoff of $95 \%$ of similarity at the nucleotide level based on generic concept [21].

DOTUR was also used to generate rarefaction curves data, diversity (Shannon) and species richness (Chao1) indices for each library. To evaluate whether the populations were statistically distinct, J-Libshuff software was used [22]. Finally, one sequence from each OTU obtained was aligned together with closely related sequences retrieved from GenBank and used to generate a Neighbor-Joining phylogenetic tree with the Kimura-2 parameter and a bootstrap value of 1000 in MEGA5 [23].

\subsection{Molecular Screening for Cyanobacterial Metabolites Production}

The presence of cyanobacterial genes involved in toxins and protease inhibitors biosynthesis in the studied lagoons was firstly evaluated by PCR amplification. The PCR for cyanobacterial toxin genes was conducted using the following primers: anatoxin-ALM_F/ALM_R [24]; cylindrospermopsin-CYLATF/CYLATR [25] and cynsulF/cylnamlR [26]; microcystin-mcyE_F2 and mcyE_R4 [27] and saxitoxin OCT-F/OCT-R [28], according to the conditions originally detailed in the publications describing each of these primers pairs (Supplementary data: Table S1).

The proteases inhibitors synthetases were investigated using the primers for aeruginosin aerA_F/aerB_R and cyanopeptolin mcnC_F/mcnE_R [29]. The amplification of these genes was verified by electrophoresis in 1\% agarose gel by comparison with 100 bp DNA ladder (Invitrogen).

\subsection{Extraction of Cyanobacterial Metabolites and Chemical Analysis}

Water samples were centrifuged at $9000 \times \mathrm{g}$ at $22^{\circ} \mathrm{C}$ for $5 \mathrm{~min}$. The supernatant was discharged and $5 \mathrm{~mL}$ of methanol and glass beads of $3 \mathrm{~mm}$ diameter were added to the pellets, following vortex agitation for $1 \mathrm{~min}$. The samples were concentrated by centrifugation at $9000 \times \mathrm{g}$ for $5 \mathrm{~min}$. and the supernatant was collected. Extracts were then dried at $55^{\circ} \mathrm{C}$ and subjected to a solid-phase extraction on a $\mathrm{C}_{18}$ reversed-phase cartridge (Phenomenex ${ }^{\circledR} 10 \mathrm{~g}$ ), using gradient in $\mathrm{H}_{2} \mathrm{O}$ in methanol. Fractions were evaporated, diluted in a solution of methanol: water:formic acid (50\%:50\%:0.1\%) and analysed using a LC/MS Agilent 6410 Triple Quadrupole equipped with Agilent 1200 Series Binary Pump SL pumping system and Agilent 1200 Autosampler (Agilent Technologies Inc. Santa Clara, CA, USA). All the parameters for data analyses were performed according to [30]. The mass spectrometry analysis was performed via direct infusion of the extracts into the ESI source of the mass spectrometer. Molecular ions were scanned in the range of 100 to $1800 \mathrm{Da}$. Cone voltage was set to $50 \mathrm{~V}$ and collision energy of $60 \mathrm{eV}$ was used.

\section{Results}

\subsection{Community Profile}

DGGE analysis was performed to represent the diversity of cyanobacteria present in the lagoons in order to di- 
rect the subsequent analyses. DGGE banding patterns showed low variation among the communities from the different water samples and suggested that there was a predominance of few OTUs in these locations (data not shown). Limeira, Taquaral and ESALQ2 lagoons showed nearly the same banding patterns. On the other hand, ESALQ1 lagoon presented the most different band profile.

The analyses of sequences obtained in clone libraries resulted in a total of 233 clones, distributed as follows: 59 from ESALQ1, 57 from ESALQ2, 57 from Limeira and 60 from Taquaral lagoons (Table 1). In total, nine different known cyanobacterial genera belonging to four different orders were identified in clone libraries when the sequences were compared with those available in the NCBI GenBank database.

Taquaral lagoon presented low richness and diversity values, revealed by the Chao1 and Shannon indices (Figure 1(a), Figure 1(b)), confirming the low cyanobacterial diversity observed in the DGGE methodology. Also, the sequences obtained for this sample match with only one known cyanobacterial genus, 49 clones out of 60 are related to Microcystis sequences and the remaining clones correspond to uncultured cyanobacteria (Table 1). Limeira and ESALQ2 water samples presented clones of three (Brasilonema, Microcystis and Pseudanabaena) and four (Anabaena, Microcystis, Nostoc and Pseudanabaena) cyanobacterial strains from different genera, respectively (Table 1). In both cases, the predominantly observed genus was Microcystis (46 and 51 clones, respectively). Only few OTUs were not possible to be affiliated to known cyanobacterial genera in those cases. Lagoons ESALQ2, Limeira and Taquaral had 89\%, 82\% and 81\%, respectively, of their sequences related to the genus Microcystis. The sample that showed the highest richness and diversity of cyanobacteria species was ESALQ1 lagoon (Figure 1(a), Figure 1(b)), presenting five different genera (Anabaena, Cylindrospermopsis, Limnococcus, Synechococcus and Woronichinia) (Table 1). In comparison to other lagoons, Limeira lagoon showed a high number of uncultured cyanobacteria. Interestingly, no sequences matching Microcystis was observed in this lagoon. The estimated sample coverage (ESC) ranged from $81 \%$ to $95 \%$ for all lagoons (Table 1). Hence, it was possible to consider that the sampled environments were well represented even presenting a low number of clones. This assumption was confirmed by the rarefaction curves calculated for the clone libraries, which were close to reaching the asymptote for all samples, thus indicating that the probability of finding new OTUs was very low, especially in ESALQ2 and Limeira samples (Figure 2). The libraries reciprocal coverage evaluated by $\int$-Libshuff showed that the lagoons differ statistically from each other, with the exception of Taquaral and ESALQ2, which showed a p value of 0.4914, indicating an overlapping of sequences in these samples.

Table 1. Cyanobacterial genera closest to the sequences obtained in this work; Comparison of OTUs; and ESC for clone libraries of cyanobacteria 16S rRNA genes sampled in four lagoons located in the state of São Paulo.

\begin{tabular}{|c|c|c|c|c|}
\hline & Limeira & Taquaral & ESALQ1 & ESALQ2 \\
\hline Uncultured cyanobacteria & 4 & 11 & 35 & 3 \\
\hline Cylindrospermopsis & & & 5 & \\
\hline Woronichinia & & & 4 & \\
\hline Synechococcus & & & 13 & \\
\hline Limnococcus & & & 1 & \\
\hline Microcystis & 46 & 49 & & 51 \\
\hline Brasilonema & 3 & & & \\
\hline Pseudanabaena & 4 & & & 1 \\
\hline Anabaena & & & 1 & 1 \\
\hline Nostoc & & & & 1 \\
\hline Clones $^{1}$ & 57 & 60 & 59 & 57 \\
\hline OTUs $^{2}$ & 20 & 21 & 29 & 20 \\
\hline $\mathrm{ESC}^{3}$ & 0.825 & 0.817 & 0.814 & 0.947 \\
\hline
\end{tabular}

\footnotetext{
${ }^{1}$ No. of clones of each genus found per lagoon; ${ }^{2}$ Operational taxonomic units; ${ }^{3}$ Estimated sample coverage.
} 


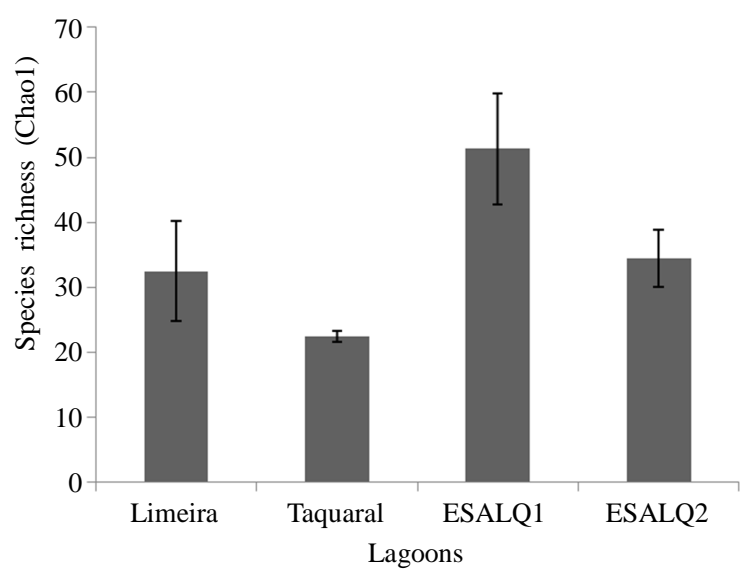

(a)

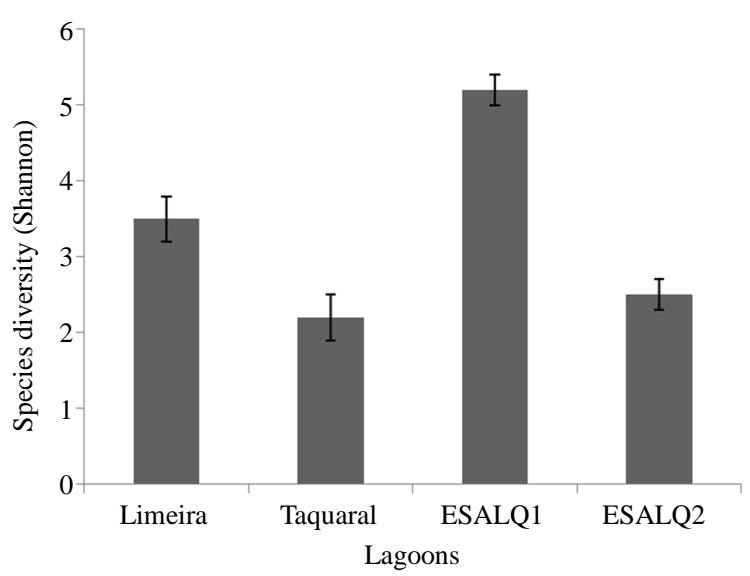

(b)

Figure 1. Comparison of richness (a) and diversity (b) indices derived from 16S rRNA gene clone libraries of four lagoons.

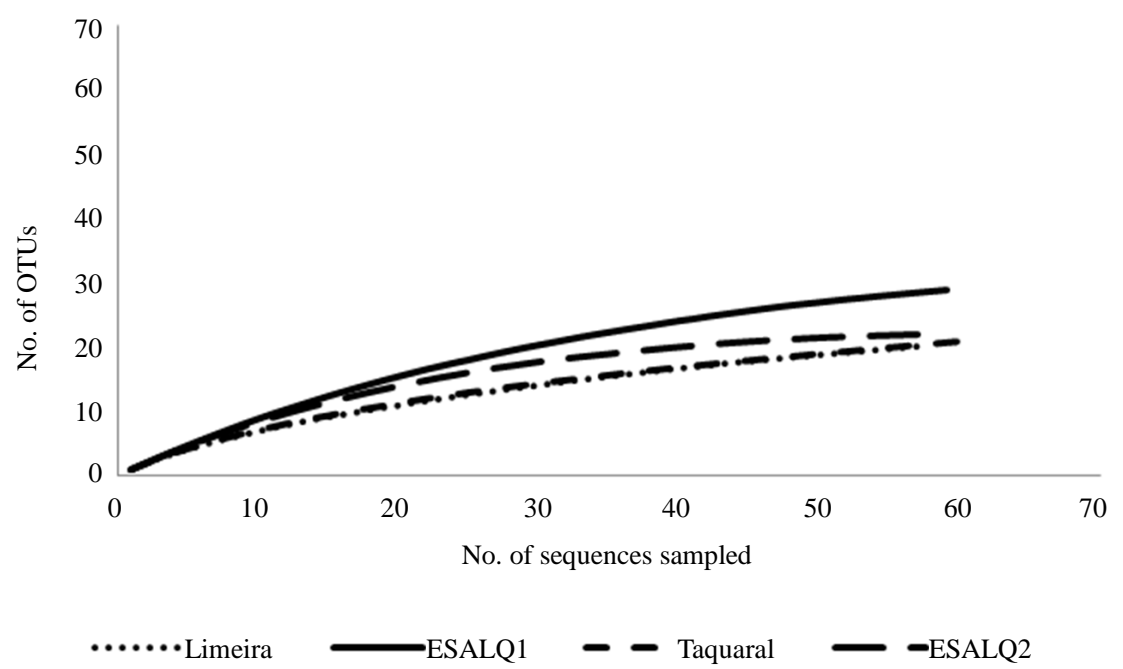

Figure 2. Rarefaction curves of sequences of cyanobacterial 16S rDNA clone libraries from the four lagoons samples, calculated by DOTUR with a $3 \%$ evolutionary distance cutoff.

When the sequences of all clone libraries were grouped together, a total of 53 OTUs was found, with 27 singletons among them (13 from ESALQ1, 4 from Taquaral, 6 from ESALQ2 and 4 from Limeira). No OTU was observed in common for all the lagoons. OTU 1 was the most abundant in number of sequences (59), including 21 from ESALQ2, 21 from Limeira and 17 from Taquaral. The representative sequence of this OTU grouped with Microcystis sequences and with others OTUs in the phylogenetic tree; OTUs 2, 3 and 8 also presented sequences from those three lagoons, but in lower numbers; nine OTUs (4, 6, 9, 11, 13, 14, 17, 18 and 26) were observed only in ESALQ1; three OTUs (12, 19 and 20) were observed only in Taquaral lagoon; four (16, 21, 23 and 24) were observed in Limeira lagoon; one (25) was observed in ESALQ2 lagoon; OTUs 5, 15 and 22 were represented by sequences from Limeira and ESALQ2 lagoons; OTU 7 was represented by sequences of Taquaral and ESALQ1 lagoons; OTU 10 was represented by sequences from Taquaral and ESALQ2 lagoons.

The phylogenetic tree was constructed using a representative sequence of each 53 OTUs. Among these OTUs, 30 grouped with sequences from genera identified as representative of the order Chroococcales (Gloeocapsa, Limnococcus, Microcystis, Snowella and Woronichinia); five grouped with genera from the order Nostocales (Brasilonema, Cylindrospermopsis and Nostoc); five grouped with genera from the order Synechococcales (Synechococcus and Prochlorococcus); five with genera from Pseudanabaenales order (Leptolyngbya and Pseudanabaena); three with genera from the order Oscillatoriales (Halospirulina and Planktothrichoides); and five OTUs did not group with cyanobacteria from any known genus (Figure 3). 


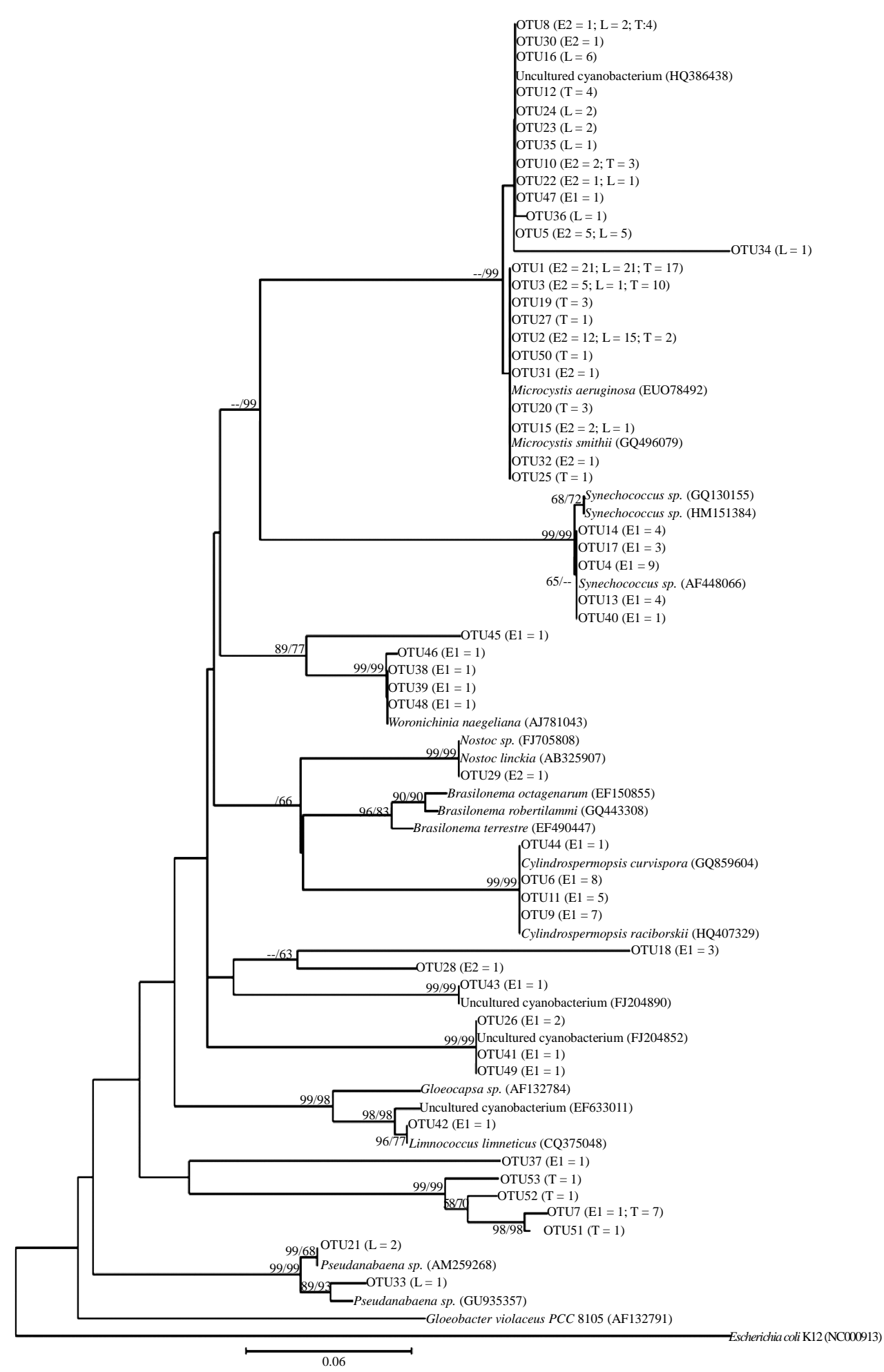

Figure 3. Phylogenetic tree based on Neighbor-Joining analysis of the partial 16S rDNA sequences of four lagoons, in relation to sequences obtained from GenBank. Bootstrap values (expressed as percentages of 1000 resamplings) $>50 \%$ are shown at branch points. The scale indicates the substitutional distance based on Kimura's two-parameter model. The sequences that were obtained from this study are designed as OTU. The numbers in parentheses indicate the number of sequences of each OUT from ESALQ1 (E1), ESALQ2 (E2), Limeira (L) and Taquaral (T) clone libraries. 


\subsection{Molecular Screening for Secondary Metabolites Production}

The PCR-amplification of genes encoding sequences related to proteases inhibitors synthetase biosynthesis resulted in positive results for aeruginosin in samples from Limeira, Taquaral and ESALQ2 lagoons and for cyanopeptolin in Limeira and ESALQ2 lagoons (Table 2).

Genes involved in microcystin production were observed in Limeira, Taquaral and ESALQ2 lagoons, and with saxitoxin only in ESALQ1 lagoon. It was not possible to verify amplification for anatoxin and cylindrospermopsin to the evaluated samples (Table 2).

\subsection{Chemical Screening}

Chemical analysis performed by LC-MS/MS confirmed the presence of aeruginosin in Limeira, Taquaral and ESALQ2 samples; and cyanopeptolin and microcystin in Limeira samples (Table 2). Anatoxin, saxitoxin and cylindrospermopsin were not detected in any sample. Microcystin-LR was identified in the sample of Limeira lagoon and showed two variants, m/z 981 and 995 (Supplementary data: Figure S1 and Figure S2). The fragmentation of the toxins was performed and confirmed by the presence of the ion $\mathrm{m} / \mathrm{z} 135$, corresponding to the unusual Adda group, the molecule responsible for the toxicity of microcystin. The fragmentation of ion at $\mathrm{m} / \mathrm{z}$ 981 observed in Limeira sample indicated that the molecule is the variant (D-Asp ${ }^{3}$ ) microcystin-LR due to the presence of the ions $\mathrm{m} / \mathrm{z}$ 70, 86, 135, 213 and 375, corresponding to Arg, Leu (immonium ion), Adda, Glu + Mdha + H and Adda + Glu + Mdha, respectively [31]. In Figure 4 was showed the generalized structure of microcystin-LR.

Fragmentations of aeruginosins showed a strong signal of the ion at $\mathrm{m} / \mathrm{z} 140$, corresponding to the Choi immonium-(acid 2-carboxy-6-hydroxyoctahydroindole), which is indicative of aeruginosin. The fragmentation of two aeruginosins at $m / z 561$ and 593 (Supplementary data: Figure S3 and Figure S4), ions at m/z 309, 291 and 266 were detected, indicating the presence of Choi-Argininal. Fragments associated with Hpla (lactic

Table 2. Secondary metabolites identified in water samples by gene amplification and LC-MS/MS.

\begin{tabular}{|c|c|c|c|c|c|c|c|c|c|}
\hline \multirow{2}{*}{ Sample } & \multicolumn{6}{|c|}{$\mathrm{PCR}^{*}$} & \multirow{2}{*}{ Secondary metabolite } & \multirow{2}{*}{$m / z$} & \multirow{2}{*}{ Related biological activities } \\
\hline & mcy & sxt & aer & $\mathrm{mcn}$ & ana & суг & & & \\
\hline \multirow[t]{2}{*}{ ESALQ1 } & - & + & - & - & - & - & - & - & - \\
\hline & & & & & & & Aeruginosin & 601 & - \\
\hline \multirow[t]{2}{*}{ ESALQ2 } & + & - & + & + & - & - & Aeruginosin & 635 & - \\
\hline & & & & & & & Aeruginosin & 669 & - \\
\hline \multirow[t]{6}{*}{ Taquaral } & + & - & + & - & - & - & Aeruginosin & 601 & - \\
\hline & & & & & & & Aeruginosin & 633 & - \\
\hline & & & & & & & Aeruginosin & 561 & - \\
\hline & & & & & & & Aeruginosin & 593 & Protease inhibitor \\
\hline & & & & & & & Aeruginosin & 593 & Protease inhibitor \\
\hline & + & - & + & + & - & - & Cyanopeptolin & 505 & - \\
\hline \multirow{6}{*}{ Limeira } & & & & & & & Cyanopeptolin & 959 & Protease inhibitor \\
\hline & & & & & & & Cyanopeptolin & 969 & - \\
\hline & & & & & & & Cyanopeptolin & 973 & Protease inhibitor \\
\hline & & & & & & & Micropeptin A & 987 & Protease inhibitor \\
\hline & & & & & & & Desmethyl-MC-LR & 981 & Phosphatase inhibitor \\
\hline & & & & & & & Microcystin-LR & 995 & Phosphatase inhibitor \\
\hline
\end{tabular}

${ }^{*}$ mcy—microcystin; sxt—saxitoxin; aer—aeruginosin; mcn—cyanopeptolin; ana—anatoxin and homoanatoxin; cyr—cylindrospermopsin. 
hydroxyphenyl) showed an increase in mass corresponding to the level of chlorination in the molecule: aeruginosin $\mathrm{m} / \mathrm{z} 593$ and 601 (Supplementary data: Figure S5 and Figure S6) referred to the molecule without chlorine (ion $\mathrm{m} / \mathrm{z}$ 250); aeruginosin $\mathrm{m} / \mathrm{z}$ 601, 635 and 669 (Supplementary data: Figures S7-S9) presented one chlorine (ion $\mathrm{m} / \mathrm{z}$ 284); aeruginosin $\mathrm{m} / \mathrm{z} 627$ (Supplementary data: Figure S10) contained two chlorines (ion $\mathrm{m} / \mathrm{z} 318$ ). Only aeruginosin $\mathrm{m} / \mathrm{z} 593$ has been previously reported [32]. In Figure 5 was showed the generalized structure of aeruginosin.

In the fragmentation spectra of cyanopeptolins they all showed a strong signal of the ion $\mathrm{m} / \mathrm{z} 150$ (MTyr immonium), which is indicative of cyanopeptolin. The occurrence of the fragment $\mathrm{m} / \mathrm{z} 115$ (Ahp) also supports the identification of cyanopeptolins (Supplementary data: Figures S11-S15). Fragments with molar masses of 127 and 198 Da appear when chlorination of Tyr occurs [33], which was not observed in any sample. The cyanopeptolins detected showed m/z 505, 959 [34], 969, 973 [35], and 987 [36]. In Figure 6 was showed the generalized structure of cyanopeptolin.

\section{Discussion}

In Brazil many cases of cyanobacterial blooms in lakes, lagoons and reservoirs have been reported [37]-[39]. Blooms usually have low diversity, with the predominance of one or few species. In this study, DGGE and clone<smiles>C=C(C(=O)N[C@@H](C)C(=O)N[C@@H](CC(C)C)C(=O)N[C@@H](C(=O)O)[C@@H](C)C(=O)N[C@@H](CCCNC(=N)N)C(=O)N[C@@H](/C=C/C(C)=C/[C@@H](C)[C@H](O)Cc1ccccc1)[C@@H](C)C(=O)N[C@@H](CCC(=O)N(C)C(=O)O)C(=O)O)[C@H](C)Cc1ccccc1</smiles>

Figure 4. Generalized structure of microcystin-LR.<smiles>[R]NC([R])C(=O)N1C(C([R3])=O)CC2CCC(O)CC21</smiles>

Figure 5. Generalized structure of aeruginosin. 


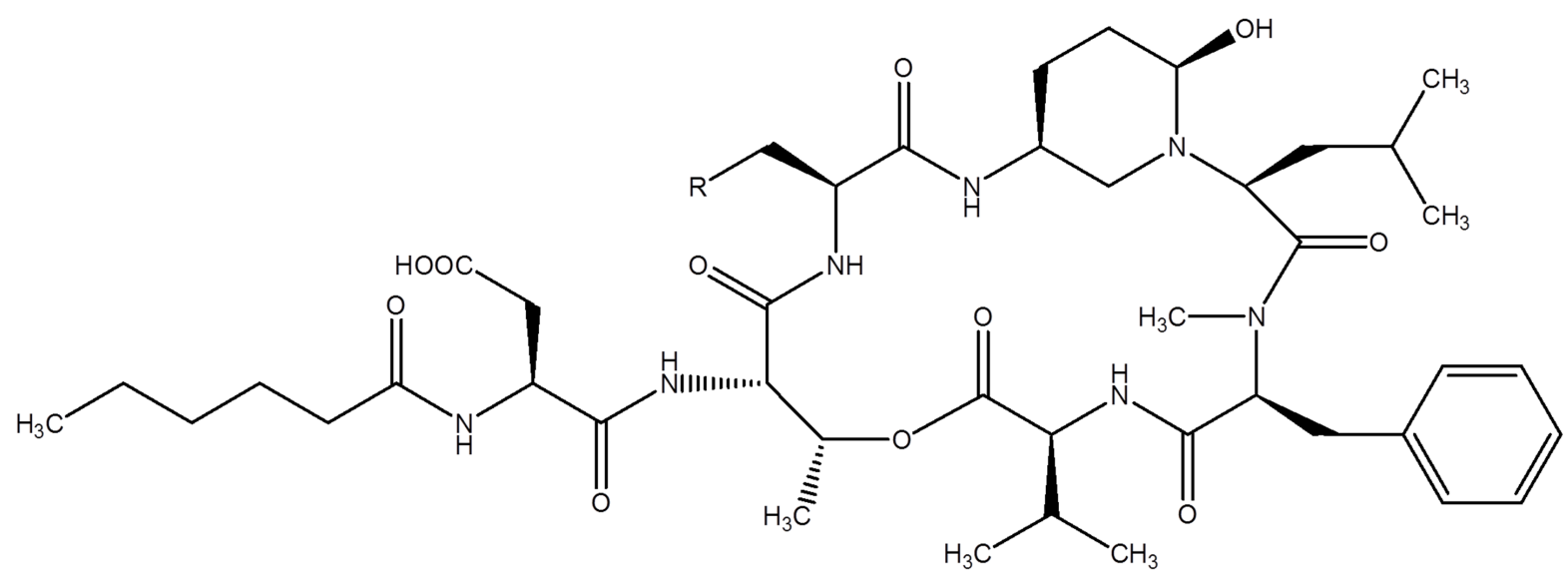

Figure 6. Generalized structure of cyanopeptolin.

libraries were useful to address these conditions, since a low number of OTUs was observed in all libraries and DGGE banding patterns showed a predominance of few OTUs.

Although DGGE was originally used for the analysis of structural transitions of nucleic acids and proteinnucleic acid complexes [40], it has become a widely used tool in microbial ecology studies. However, this technique is limited by a biased amplification of sequences from some populations inside a complex microbial community during PCR, so that the band profile may be composed of bands representing the most abundant OTUs only [41]. In this way, amplicons from rarer species may not be detected, especially when they represent less than $1 \%$ of the total community [42]. Despite this bias, as cyanobacterial blooms are generally characterised by the low diversity as observed in this study, the results obtained in the analyses were consistent with the expected community compositions in cyanobacterial blooms. Therefore, the techniques used were satisfactorily accurate for evaluating the sampled environments.

Species assigned to the genera assessed in this study have been reported as producers of several cyanotoxins: Microcystis as producers of the hepatotoxin microcystin [30] [43] and the neurotoxin anatoxin-a [44]; Cylindrospermopsis as producers of the hepatotoxin cylindrospermopsin [45] [46] and the neurotoxin saxitoxin [44] [46]; Anabaena as producers of the anatoxin-a and anatoxin-a(S) [44] [47], cylindrospermopsin [44], microcystin and saxitoxin [45]; Nostoc as producers of microcystin [45] [48]; and Woronichinia as producers of microcystin [49]. Taquaral was the only lagoon in which previous studies had been conducted [50] [51], in which the genus Microcystis was found. Therefore, blooms by cyanobacteria related to this genus have been known for about 20 years in this lagoon.

Sant’Anna et al. [38] studied six reservoirs belonging to the upper Tietê Basin, São Paulo (Billings, Guarapiranga, Jundiaí, Pirapora, Ponte Nova and Taiaçupeba) and found a predominance of Chroococcales, followed by Nostocales and Oscillatoriales orders. These findings are similar to this study, wich also showed a predominance of species belonging to Chroococcales, followed by Nostocales, Oscillatoriales, Pseudanabaenales and Synechococcales orders.

According to [52], the genera Microcystis and Anabaena have the highest number of toxic species reported in Brazil, while M. aeruginosa and C. raciborskii are the most widely distributed toxic cyanobacteria in the country, occurring in several areas from the tropical and subtropical regions. The coexistence of these species and the alternation of their predominance have been recorded in an urban eutrophic lake in Brazil [53].

Richness and diversity of species evaluated by the Chao 1 and Shannon index had similar results. ESALQ1 was the most diverse environment and Taquaral the lowest. The fact that Taquaral lagoon presented the lowest rates can be explained by the bloom of Microcystis sp. which occurred in that site. When a Microcystis bloom occurs, their mucilaginous colonies provide a high degree of shading to the other phytoplanktonic species, thus disfavouring their growth. Consequently, diversity and richness decrease significantly [54]. Other factors that allow Microcystis dominance in many aquatic ecosystems are high nutrient loading; rising temperatures, because cyanobacteria generally grow better at higher temperatures than do other phytoplankton species; enhanced stratification, reducing water vertical mixing; physiological and biochemical adaptations to growth in a saline environment, and the presence of intracellular gas vesicles, which make the cells buoyant, shading underlying 
non-buoyant phytoplankton and suppressing their opponents through competition for light [55].

OTUs with close phylogenetic relationships with Microcystis sp. were the most numerous (146 sequences out of a total of 233), totalising $63 \%$ of all sequences obtained, which demonstrates that this genus predominates in most of the studied lagoons, with the exception of ESALQ1. Following Microcystis, OTUs related to Cylindrospermopsis and Synechococcus represented $\sim 8 \%$ of the total of sequences, with 18 related sequences (Table 1). Therefore, the large majority of cyanobacteria assessed, with approximately $70 \%$ of all the sequences obtained, are phylogenetically close to these three genera.

The specific primer sets used in this study successfully amplified gene sequences involved in the biosynthesis of aeruginosin, cyanopeptolin, microcystin and saxitoxin from samples of the four lagoons studied. Cyanobacteria produce many bioactive compounds, which could present toxicity [56]. The genus Microcystis can synthesise microcystin and other peptides, such as the protease inhibitors aeruginosin and cyanopeptolin [30]. These proteases production interferes with the grazing ability of some mesozooplankton, e.g. inhibiting Daphnia's digestive proteases [57], leading to the decline of freshwater herbivores in the environment.

The positive results found in the amplification of aeruginosin, cyanopeptolin and microcystin genes must be due to the elevated presence of this genus in most samples. Aeruginosins present various levels of inhibitory activity against serine proteases. This type of structure and functional characteristics are responsible for the affinity of aeruginosin with the catalytic site of trypsin, thrombin and other serine proteases involved in blood clotting. Cyanopeptolins were found to be the most common cyanopeptide produced by the genus Microcystis in a study conducted by [58]. They reported that cyanopeptolin production was detected in $60 \%$ of the isolated colonies of Microcystis.

In Brazil, Cylindrospermopsis raciborskii produces saxitoxin [37] [59] [60], but it is reported as a cylindrospermopsin-producer in other regions of the world [61]-[67]. Based on this fact and the observation of OTUs related to this species in samples from ESALQ1, it is very likely that the saxitoxin genes detected in the lagoon were provided by members of $C$. raciborskii.

According to mass spectrometry analyses of ESALQ2 sample, aeruginosins were present, which can be produced by the genera Microcystis and Nostoc [68], both genera found in this sample. Limeira sample presented aeruginosin, cyanopeptolin and microcystin variants. This can be attributed to the high abundance of Microcystis strains in the lagoon and this genus is known to produce these molecules. Micropeptin, a cyanopeptide that belongs to the cyanopeptolin class, was also found in the sample indicating the presence of several congeners. In the case of Taquaral sample, a lagoon with bloom of Microcystis, only aeruginosins were detected. No secondary metabolites were found in ESALQ1 sample, although several cyanobacterial genera could be observed (Table 2).

\section{Conclusion}

In conclusion, the present study has provided genetic and chemical information on samples collected from cyanobacterial blooms occurring in four lagoons located in the state of São Paulo, Brazil, for the first time. Since microcystin-producing cyanobacteria have been identified, this represents a human or animal health threat, a finding which emphasizes the need to introduce monitoring activities with regard to toxic cyanobacterial species, including analysis of the cyanobacterial toxins. According to this study, blooms of cyanobacteria in lagoons produce a wide variety of toxic or nontoxic metabolites. The most abundant of the toxic molecules found by molecular approaches were microcystins, while the molecules with no known toxicity to humans generally belong to the group of peptides of the protease inhibitors class, such as aeruginosin and cyanopeptolin. The integrated methodologies used in this study were a useful tool to provide informations for scientific community and members of public health.

\section{Acknowledgements}

This study was supported by grants from The State of São Paulo Research Foundation (FAPESP-2009/05474-5 and 2014/15760-3). M.F. Fiore would like to thank CNPq for a research fellowship (308299/2009-4). M.E. Silva-Stenico was the recipient of a postdoctoral fellowship from FAPESP (2010/09867-9) and CNPq (151931/ 2010-0). J. Rigonato was the recipient of a postdoctoral fellowship from CNPq (383187/2010-9). D.O. Alvarenga was supported by a graduate fellowship from FAPESP (2011/08092-6) and L.M. Elias was supported by a graduate fellowship from CNPq (143275/2011-9) and FAPESP (2012/02000-5). We thank Dr. V. Tornisielo for 
LC-MS/MS analysis support in the Ecotoxicology Laboratory, CENA/USP.

\section{References}

[1] Siqueira, D.B. and Oliveira-Filho, E.C. (2005) Cianobactérias de água doce e saúde pública: Uma revisão. Universitas Ciências da Saúde, 3, 109-127.

[2] Paerl, H.W. (2008) Nutrient and Other Environmental Controls of Harmful Cyanobacterial Blooms along the Freshwater-Marine Continuum. Advances in Experimental Medicine and Biology, 619, 217-237. http://dx.doi.org/10.1007/978-0-387-75865-7_10

[3] Sivonen, K. and Jones, G. (1999) Cyanobacterial Toxins. In: Chorus, I. and Bartram, J., Eds., Toxic Cyanobacteria in Water: A Guide to Their Public Health Consequences, Monitoring, and Management, E \& FN Spon, London, 41-111.

[4] Carmichael, W.W., Azevedo, S.M., An, J.S., Molica, R.J., Jochimsen, E.M., Lau, S., Rinehart, K.L., Shaw, G.R. and Eaglesham, G.K. (2001) Human Fatalities from Cyanobacteria: Chemical and Biological Evidence for Cyanotoxins. Environmental Health Perspective, 109, 663-668.

[5] Merel, S., Walker, D., Chicana, R., Snyder, S., Baurès, E. and Thomas, O. (2013) State of Knowledge and Concerns on Cyanobacterial Blooms and Cyanotoxins. Environmental International, 59, 303-327. http://dx.doi.org/10.1016/j.envint.2013.06.013

[6] Lawton, L.A., Edwards, C. and Codd, G.A. (1994) Extraction and High Performance Liquid Chromatographic Method for the Determination of Microcystins in Raw and Treated Water. Analyst, 119, 1525-1530. http://dx.doi.org/10.1039/an9941901525

[7] Watanabe, M.F., Ohishi, S., Harada, K.I., Matsuura, K., Kawai, H. and Suzuki, M. (1988) Toxins Contained in Microcystis Species of Cyanobacteria (Blue-Green Algae). Toxicon, 26, 1017-1025. http://dx.doi.org/10.1016/0041-0101(88)90200-0

[8] Oehrle, S.A., Southwell, B. and Westrick, J. (2010) Detection of Various Freshwater Cyanobacterial Toxins Using Ultra-Performance Liquid Chromatography Tandem Mass Spectrometry. Toxicon, 55, 965-972. http://dx.doi.org/10.1016/j.toxicon.2009.10.001

[9] An, J. and Carmichael, W.W. (1994) Use of a Colorimetric Protein Phosphatase Inhibition Assay and Enzyme Linked Immunosorbent Assay for the Study of Microcystins and Nodularins. Toxicon, 32, 1495-1507. http://dx.doi.org/10.1016/0041-0101(94)90308-5

[10] Al-Tebrineh, J., Gehringer, M.M., Akcaalan, R. and Neilan, B.A. (2011) A New Quantitative PCR Assay for the Detection of Hepatotoxigenic Cyanobacteria. Toxicon, 57, 546-556. http://dx.doi.org/10.1016/j.toxicon.2010.12.018

[11] Molica, R.J.R. and Azevedo, S.M.F.O. (2009) Ecofisiologia de cianobactérias produtoras de cianotoxinas. Oecologia Brasiliensis, 13, 229-246.

[12] Neilan, B.A., Jacobs, D., Del Dot, T., Blackall, L.L., Hawkins, P.R., Cox, P.T. and Goodman, A.E. (1997) rRNA Sequences and Evolutionary Relationships among Toxic and Nontoxic Cyanobacteria of the Genus Microcystis. International Journal of Systematic Bacteriology, 47, 693-697. http://dx.doi.org/10.1099/00207713-47-3-693

[13] Nübel, U., Garcia-Pichel, F. and Muyzer, G. (1997) PCR Primers to Amplify 16S rRNA Genes from Cyanobacteria. Applied and Environmental Microbiology, 63, 3327-3332.

[14] Rigonato, J., Alvarenga, D.O., Andreote, F.D., Dias, A.C.F., Melo, I.S., Kent, A. and Fiore, M.F. (2012) Cyanobacterial Diversity in the Phyllosphere of a Mangrove Forest. FEMS Microbiology Ecology, 80, 312-322. http://dx.doi.org/10.1111/j.1574-6941.2012.01299.x

[15] Blum, H., Beier, H. and Gross, H. (1987) Improved Silver Staining of Plant Proteins, RNA and DNA in Polyacrylamide Gels. Electrophoresis, 8, 93-99. http://dx.doi.org/10.1002/elps.1150080203

[16] Sambrook, J. and Russel, D.W. (2001) Molecular Cloning: A Laboratory Manual. 3rd Edition, Cold Spring Harbor Laboratory, New York.

[17] Drummond, A.J., Ashton, B., Cheung, M., Heled, J., Kearse, M., Moir, R., Scones-Havas, S., Thierer, T. and Wilson, A. (2009) Geneious v4.7. http://www.geneious.com/

[18] Thompson, J.D., Higgins, D.G. and Gibson, T.J. (1994) CLUSTAL-W: Improving the Sensitivity of Progressive Multiple Sequence Alignment through Sequence Weighting, Position-Specific Gap Penalties and Weigh Matrix Choice. Nucleic Acids Research, 22, 4673-4680. http://dx.doi.org/10.1093/nar/22.22.4673

[19] Felsenstein, J. (1985) Confidence Limits on Phylogenies: An Approach Using the Bootstrap. Evolution, 39, $783-791$. http://dx.doi.org/10.2307/2408678

[20] Schloss, P.D. and Handelsman, J. (2005) Introducing DOTUR, a Computer Program for Defining Operational Taxonomic Units and Estimating Species Richness. Applied and Environmental Microbiology, 71, 1501-1506. 
http://dx.doi.org/10.1128/AEM.71.3.1501-1506.2005

[21] Komarék, J. (2010) Recent Changes (2008) in Cyanobacteria Taxonomy Based on a Combination of Molecular Background with Phenotype and Ecological Consequences (Genus and Species Concept). Hydrobiologia, 639, 245-259. http://dx.doi.org/10.1007/s10750-009-0031-3

[22] Schloss, P.D., Larget, B.R. and Handelsman, J. (2004) Integration of Microbial Ecology and Statistics: A Test to Compare Gene Libraries. Applied and Environmental Microbiology, 70, 5485-5492. http://dx.doi.org/10.1128/AEM.70.9.5485-5492.2004

[23] Tamura, K., Peterson, D., Peterson, N., Stecher, G., Nei, M. and Kumar, S. (2011) MEGA5: Molecular Evolutionary Genetics Analysis Using Maximum Likelihood, Evolutionary Distance, and Maximum Parsimony Methods. Molecular Biology and Evolution, 28, 2731-2739. http://dx.doi.org/10.1093/molbev/msr121

[24] Méjean, A., Mann, S., Maldiney, T., Vassiliadis, G., Lequin, O. and Loux, O. (2009) Evidence That Biosynthesis of the Neurotoxic Alkaloids Anatoxin-a and Homoanatoxin-a in the Cyanobacterium Oscillatoria PCC 6506 Occurs on a Modular Polyketide Synthase Initiated by L-Proline. Journal of the American Chemical Society, 131, 7512-7513. http://dx.doi.org/10.1021/ja9024353

[25] Kellmann, R., Mills, T. and Neilan, B.A. (2006) Functional Modeling and Phylogenetic Distribution of Putative Cylindrospermopsin Biosynthesis Enzymes. Journal of Molecular Evolution, 62, 267-280. http://dx.doi.org/10.1007/s00239-005-0030-6

[26] Mihali, T.K., Kellmann, R., Muenchhoff, J., Barrow, K.D. and Neilan, B.A. (2008) Characterization of the Gene Cluster Responsible for Cylindrospermopsin Biosynthesis. Applied and Environmental Microbiology, 74, 716-722. http://dx.doi.org/10.1128/AEM.01988-07

[27] Rantala, A., Fewer, D.P., Hisbergues, M., Rouhiainen, L., Valtomaa, J., Börner, T. and Sivonen, K. (2004) Phylogenetic Evidence for the Early Evolution of Microcystin Synthesis. Proceedings of the National Academy of Sciences of the United States, 101, 568-573. http://dx.doi.org/10.1073/pnas.0304489101

[28] Fiore, M.F., Crespim, E., Silva-Stenico, M.E., Genuario, D.B. and Silva, C.S.P. (2010) Putative Saxitoxin Gene in Terrestrial Heterocytous Cyanobacteria Isolated from Brazilian Rainforests. The 8th International Conference on Toxic Cyanobacteria, Istambul.

[29] Cadel-Six, S., Dauga, C., Castets, A.M., Rippka, R., Bouchier, C., Marsac, N.T. and Welker, M. (2008) Halogenase Genes in Nonribosomal Peptide Synthetase Gene Clusters of Microcystis (Cyanobacteria): Sporadic Distribution and Evolution. Molecular Biology and Evolution, 25, 2031-2041. http://dx.doi.org/10.1093/molbev/msn150

[30] Silva-Stenico, M.E., Silva, C.S.P., Lorenzi, A.S., Shishido, T.K., Etchegaray, A., Lira, S.P., Moraes, L.A.B. and Fiore, M.F. (2011) Non-Ribosomal Peptides Produced by Brazilian Cyanobacterial Isolates with Antimicrobial Activity. Microbiological Research, 166, 161-175. http://dx.doi.org/10.1016/j.micres.2010.04.002

[31] Welker, M., Fastner, J., Erhard, M. and von Döhren, H. (2002) Applications of MALDI-TOF MS Analysis in Cyanotoxin Research. Environmental Toxicology, 17, 367-374. http://dx.doi.org/10.1002/tox.10073

[32] Welker, M. and Erhard, M. (2007) Consistency between Chemotyping of Single Filaments of Planktothrix rubescens (Cyanobacteria) by MALDI-TOF and the Peptide Patterns of Strains Determined by HPLC-MS. Journal of Mass Spectrometry, 48, 1062-1068. http://dx.doi.org/10.1002/jms.1237

[33] Welker, M. and von Döhren, H. (2006) Cyanobacterial Peptides—Nature’s Own Combinatorial Biosynthesis. FEMS Microbiology Reviews, 30, 530-563. http://dx.doi.org/10.1111/j.1574-6976.2006.00022.x

[34] Czarnecki, O., Henning, M., Lippert, I. and Welker, M. (2006) Identification of Peptide Metabolites of Microcystis (Cyanobacteria) That Inhibit Trypsin-Like Activity in Planktonic Herbivorous Daphnia (Cladocera). Environmental Microbiology, 8, 77-87. http://dx.doi.org/10.1111/j.1462-2920.2005.00870.x

[35] Welker, M., Brunke, M., Preussel, K., Lippert, I. and von Döhren, H. (2004) Diversity and Distribution of Microcystis (Cyanobacteria) Oligopeptide Chemotypes from Natural Communities Studied by Single Colony Mass Spectrometry. Microbiology, 150, 1785-1796. http://dx.doi.org/10.1099/mic.0.26947-0

[36] Okino, T., Matsuda, H., Murakami, M. and Yamaguchi, K. (1993) Microginin, an Angiotensin-Converting Enzyme Inhibitor from the Blue-Green Alga Microcystis aeruginosa. Tetrahedron Letters, 34, 501-504. http://dx.doi.org/10.1016/0040-4039(93)85112-A

[37] Molica, R.J.R., Onodera, H., García, C., Rivas, M., Andrinolo, D., Nascimento, S., Meguro, H., Oshima, Y., Azevedo, S.M.F.O. and Lagos, N. (2002) Toxins in the Freshwater Cyanobacterium Cylindrospermopsis raciborskii (Cyanophyceae) Isolated from Tabocas Reservoir in Caruaru, Brazil, Including Demonstration of a New Saxitoxin Analogue. Phycologia, 41, 606-611. http://dx.doi.org/10.2216/i0031-8884-41-6-606.1

[38] Sant'Anna, C.L., Melcher, S.S., Carvalho, M.C., Gemelgo, M.P. and Azevedo, M.T.P. (2007) Planktic Cyanobacteria from Upper Tietê Basin Reservoirs, SP, Brazil. Revista Brasileira de Botânica, 30, 1-17.

[39] Sotero-Santos, R.B., Carvalho, E.G., Dellamano-Oliveira, M.J. and Rocha, O. (2008) Occurrence and Toxicity of an 
Anabaena Bloom in a Tropical Reservoir (Southeast Brazil). Harmful Algae, 7, 590-598. http://dx.doi.org/10.1016/j.hal.2007.12.017

[40] Rosembaum, V. and Riesner, D. (1987) Temperature-Gradient Gel Electrophoresis: Thermodynamic Analysis of Nucleic Acids and Proteins in Purified Form and in Cellular Extracts. Biophysical Chemistry, 26, 235-246. http://dx.doi.org/10.1016/0301-4622(87)80026-1

[41] Vetriani, C., Jannasch, H.W., MacGregor, B.J., Stahl, D.A. and Reysenbach, A.L. (1999) Population Structure and Phylogenetic Characterization of Marine Benthic Archaea in Deep-Sea Sediments. Applied and Environmental Microbiology, 65, 4375-4384.

[42] Muyzer, G. (1999) DGGE/TGGE a Method for Identifying Genes from Natural Ecosystems. Current Opinion in Microbiology, 2, 317-322. http://dx.doi.org/10.1016/S1369-5274(99)80055-1

[43] Sant’Anna, C.L., Carvalho, L.R., Fiore, M.F., Silva-Stenico, M.E., Lorenzi, A.S., Rios, F.R., Konno, K., Garcia, C. and Lagos, N. (2011) Highly Toxic Microcystis aeruginosa Strain, Isolated from São Paulo—Brazil, Produce Hepatotoxins and Paralytic Shellfish Poison Neurotoxins. Neurotoxicity Research, 19, 389-402. http://dx.doi.org/10.1007/s12640-010-9177-z

[44] Funari, E. and Testai, E. (2008) Human Health Risk Assessment Related to Cyanotoxins Exposure. Critical Reviews in Toxicology, 38, 97-125. http://dx.doi.org/10.1080/10408440701749454

[45] Jaiswal, P., Singh, R.K. and Prasanna, R. (2008) Cyanobacterial Bioactive Molecules-An Overview of Their Toxic Properties. Canadian Journal of Microbiology, 54, 701-717. http://dx.doi.org/10.1139/W08-034

[46] Hoff-Risseti, C., Dörr, F.A., Schaker, P.D.C., Pinto, E., Werner, V.R. and Fiore, M.F. (2013) Cylindrospermopsin and Saxitoxin Synthetase Genes in Cylindrospermopsis raciborskii Strains from Brazilian Freshwater. PLOS One, 8, e74238. http://dx.doi.org/10.1371/journal.pone.0074238

[47] Molica, R.J.R., Oliveira, E.J.A., Carvalho, P.V.V.C., Costa, A.P.N.S.F., Cunha, M.C.C., Melo, G.L. and Azevedo, S.M.F.O. (2005) Occurrence of Saxitoxins and an Anatoxin-a(s)-Like Anticholinesterase in a Brazilian Drinking Water Supply. Harmful Algae, 4, 743-753. http://dx.doi.org/10.1016/j.hal.2004.11.001

[48] Genuário, D.B., Silva-Stenico, M.E., Welker, M., Moraes, L.A.B. and Fiore, M.F. (2010) Characterization of a Microcystin and Detection of Microcystin Synthetase Genes from a Brazilian Isolate of Nostoc. Toxicon, 55, 846-854. http://dx.doi.org/10.1016/j.toxicon.2009.12.001

[49] Willame, R., Jurczak, T., Iffly, J., Kull, T., Meriluoto, J. and Hoffman, L. (2005) Distribution of Hepatotoxic Cyanobacterial Blooms in Belgium and Luxembourg. Hydrobiologia, 551, 99-117. http://dx.doi.org/10.1007/s10750-005-4453-2

[50] Matsumura-Tundisi, T., Hino, K. and Rocha, O. (1986) Características limnológicas da Lagoa do Taquaral (Campinas S.P.)-um ambiente hipereutrófico. Ciência e Cultura, 38, 420-425.

[51] Borges, J.T. (1998) Avaliação do estado trófico e sanitário e a adsorção de fósforo no sedimento da Lagoa do TaquaralCampinas-SP. Dissertation, Universidade Estadual de Campinas, Campinas.

[52] Sant’Anna, C.L., Azevedo, M.T.P., Werner, V.R., Dogo, C.R., Rios, F.R. and Carvalho, L.R. (2008) Review of Toxic Species of Cyanobacteria in Brazil. Algological Studies, 126, 251-265. http://dx.doi.org/10.1127/1864-1318/2008/0126-0251

[53] Crossetti, L.O. and Bicudo, C.E.M. (2008) Adaptations in Phytoplankton Life Strategies to Composed Change in a Shallow Urban Tropical Eutrophic Reservoir, Garças Reservoir, over 8 Years. Hydrobiologia, 614, 91-105. http://dx.doi.org/10.1007/s10750-008-9539-1

[54] Tucci, A. and Sant’Anna, C.L. (2003) Cylindrospermopsis raciborskii (Woloszynska) Seenayya \& Subba Raju (Cyanobacteria): Variação semanal e relações com fatores ambientais em um reservatório eutrófico, São Paulo, SP, Brasil. Revista Brasileira de Botânica, 26, 97-112.

[55] Paerl, H.W. and Huisman, J. (2008) Blooms Like It Hot. Science, 320, 57-58. http://dx.doi.org/10.1126/science.1155398

[56] Namikoshi, M. and Rinehart, K.L. (1996) Bioactive Compounds Produced by Cyanobacteria. Journal of Industrial Microbiology and Biotechnology, 17, 373-384. http://dx.doi.org/10.1007/BF01574768

[57] Schwarzenberger, A., Zitt, A., Kroth, P., Mueller, S. and Elert, E.V. (2010) Gene Expression and Activity of Digestive Proteases in Daphnia: Effects of Cyanobacterial Protease Inhibitors. BMC Physiology, 10, 6. http://dx.doi.org/10.1186/1472-6793-10-6

[58] Welker, M., Marsálek, B., Sejnohová, L. and von Döhren, H. (2006) Detection and Identification of Oligopeptides in Microcystis (Cyanobacteria) Colonies: Toward an Understanding of Metabolic Diversity. Peptides, 27, 2090-2103. http://dx.doi.org/10.1016/j.peptides.2006.03.014

[59] Lagos, N., Onodera, H., Zagatto, P.A., Andrinolo, D., Azevedo, S.M.F.O. and Oshima, Y. (1999) The First Evidence 
of Paralytic Shellfish Toxins in the Freshwater Cyanobacterium Cylindrospermopsis raciborskii, Isolated from Brazil. Toxicon, 37, 1359-1373. http://dx.doi.org/10.1016/S0041-0101(99)00080-X

[60] Ferrão-Filho, A.S., Cunha, R., Magalhães, V.F., Soares, M.C.S. and Baptista, D.F. (2007) Evaluation of Sub-Lethal Toxicity of Cyanobacteria on the Swimming Activity of Aquatic Organisms by Image Analysis. Journal of the Brazilian Society of Ecotoxicology, 2, 93-100. http://dx.doi.org/10.5132/jbse.2007.02.001

[61] Hawkins, P.R., Runnegar, M.T.C., Jackson, A.R.B. and Falconer, I.R. (1985) Severe Hepatotoxicity Caused by the Tropical Cyanobacterium (Blue-Green Alga) Cylindrospermopsis raciborskii (Woloszynska) Seenaya and Subba Raju Isolated from a Domestic Water Supply Reservoir. Applied and Environmental Microbiology, 50, 1292-1295.

[62] Saker, M.L. and Eaglesham, G.K. (1999) The Accumulation of Cylindrospermopsin from the Cyanobacterium Cylindrospermopsis raciborskii in Tissues of the Redclaw Crayfish Cherax quadricarinatus. Toxicon, 37, 1065-1077. http://dx.doi.org/10.1016/S0041-0101(98)00240-2

[63] Li, R., Carmichael, W.W., Brittain, S., Eaglesham, G.K., Shaw, G.R., Mahakhant, A., Noparatnaraporn, N., Yongmanitchai, W., Kaya, K. and Watanabe, M.M. (2001) Isolation and Identification of the Cyanotoxin Cylindrospermopsin and Deoxy-Cylindrospermposin from a Thailand Strain of Cylindrospermopsis raciborskii. Toxicon, 39, 973-980. http://dx.doi.org/10.1016/S0041-0101(00)00236-1

[64] Bernard, C., Harvey, M., Briand, J.F., Biré, R., Krys, S. and Fontaine, J.J. (2003) Toxicological Comparison of Diverse Cylindrospermopsis raciborskii Strains: Evidence of Liver Damage Caused by a French C. raciborskii Strain. Environmental Toxicology, 18, 176-186. http://dx.doi.org/10.1002/tox.10112

[65] Wood, S.A. and Stirling, D.J. (2003) First Identification of the Cylindrospermopsin-Producing Cyanobacterium Cylindrospermopsis raciborskii in New Zealand. New Zealand Journal of Marine and Freshwater Research, 37, 821-828. http://dx.doi.org/10.1080/00288330.2003.9517211

[66] Chonudomkul, D., Yongmanitchai, W., Theeragool, G., Kawachi, M., Kasai, F., Kaya, K. and Watanabe, M.M. (2004) Morphology, Genetic Diversity, Temperature Tolerance and Toxicity of Cylindrospermopsis raciborskii (Nostocales, Cyanobacteria) Strains from Thailand and Japan. FEMS Microbiology Ecology, 48, 345-355. http://dx.doi.org/10.1016/j.femsec.2004.02.014

[67] Everson, S., Fabbro, L., Kinnear, S. and Wright, P. (2011) Extreme Differences in Akinete, Heterocyte and Cylindrospermopsin Concentrations with Depth in a Successive Bloom Involving Aphanizomenon ovalisporum (Forti) and Cylindrospermopsis raciborskii (Woloszynska) Seenaya and Subba Raju. Harmful Algae, 10, 265-276. http://dx.doi.org/10.1016/j.hal.2010.10.006

[68] Silva-Stenico, M.E., Rigonato, J., Leal, M.G., Vaz, M.G.M.V., Andreote, A.P.D. and Fiore, M.F. (2012) Non-Ribosomal Halogenated Protease Inhibitors from Cyanobacterial Isolates as Attractive Drug Targets. Current Medicinal Chemistry, 19, 5205-5213. http://dx.doi.org/10.2174/092986712803530539 


\section{Supplement}

Table S1. Primers for amplification of selected genes and PCR conditions.

\begin{tabular}{|c|c|c|c|c|c|}
\hline Products & Primers & Genes (bp) & Sequences (5'-3') & PCR conditions & References \\
\hline 16S rRNA & $\begin{array}{l}27 \mathrm{~F} 1 \\
1494 \mathrm{Rc}\end{array}$ & $r r n(1467)$ & $\begin{array}{l}\text { AGAGTTTGATCCTGGCTCAG } \\
\text { TACGGCTACCTTGTTACGAC }\end{array}$ & $\begin{array}{l}95^{\circ} \mathrm{C} / 3 \mathrm{~min} ; 30 \text { cycles } \\
\left(94^{\circ} \mathrm{C} / 10 \mathrm{~s}, 50^{\circ} \mathrm{C} / 20 \mathrm{~s},\right. \\
\left.72^{\circ} \mathrm{C} / 1 \mathrm{~min}\right) ; 72^{\circ} \mathrm{C} / 7 \mathrm{~min}\end{array}$ & $\begin{array}{l}\text { Neilan } \\
\text { et al., } 1997\end{array}$ \\
\hline 16S rRNA & $\begin{array}{l}\text { CYA359F } \\
\text { CYA781Ra } \\
\text { CYA781Rb }\end{array}$ & $r r n(422)$ & $\begin{array}{l}\text { GGGGAATTTTCCGCAATGGG } \\
\text { GACTACTGGGGTATCCTAATCCCATT } \\
\text { GACTACAGGGGTATCTAATCCCTTT }\end{array}$ & $\begin{array}{l}94^{\circ} \mathrm{C} / 5 \mathrm{~min} ; 35 \text { cycles } \\
\left(94^{\circ} \mathrm{C} / 1 \mathrm{~min}, 63^{\circ} \mathrm{C} / 1 \mathrm{~min}\right. \\
\left.72^{\circ} \mathrm{C} / 1 \mathrm{~min}\right) ; 72^{\circ} \mathrm{C} / 7 \mathrm{~min}\end{array}$ & $\begin{array}{l}\text { Nüben } \\
\text { et al., } 1997\end{array}$ \\
\hline Anatoxin & $\begin{array}{l}\text { ALM_F } \\
\text { ALM_R }\end{array}$ & anaC (421) & $\begin{array}{l}\text { CTGGGGGCACAATTATTTTACTCTCACCTG } \\
\text { ACGCAAAGCTCACCСACCTCACСТCTAACT }\end{array}$ & $\begin{array}{l}94^{\circ} \mathrm{C} / 4 \mathrm{~min} ; 30 \text { cycles } \\
\left(94^{\circ} \mathrm{C} / 20 \mathrm{~s}, 45^{\circ} \mathrm{C} / 20 \mathrm{~s},\right. \\
\left.72^{\circ} \mathrm{C} / 1 \mathrm{~min}\right) ; 72^{\circ} \mathrm{C} / 7 \mathrm{~min}\end{array}$ & $\begin{array}{l}\text { Méjean } \\
\text { et al., } 2009\end{array}$ \\
\hline Cylindrospermopsin & $\begin{array}{l}\text { CYLAT-F } \\
\text { CYLAT-R }\end{array}$ & $\operatorname{cyr} A(1100)$ & $\begin{array}{l}\text { ATTGTAAATAGCTGGAATGAGTGG } \\
\text { TTAGGGAAGTAATCTTCACAG }\end{array}$ & $\begin{array}{l}94^{\circ} \mathrm{C} / 3 \min ; 30 \text { cycles } \\
\left(94^{\circ} \mathrm{C} / 10 \mathrm{~s}, 50^{\circ} \mathrm{C} / 20 \mathrm{~s} \text {, }\right. \\
\left.72^{\circ} \mathrm{C} / 1 \mathrm{~min}\right) ; 72^{\circ} \mathrm{C} / 7 \mathrm{~min}\end{array}$ & $\begin{array}{l}\text { Kellmann } \\
\text { et al., } 2006\end{array}$ \\
\hline Cylindrospermopsin & $\begin{array}{l}\text { cynsulf-F } \\
\text { cylnam-R }\end{array}$ & cyrJ (780) & $\begin{array}{l}\text { CTTCTCTCСTTTCССТAT } \\
\text { GAGTGAAAATGCGTAGAACTTG }\end{array}$ & $\begin{array}{l}94^{\circ} \mathrm{C} / 3 \mathrm{~min} ; 30 \text { cycles } \\
\left(94^{\circ} \mathrm{C} / 10 \mathrm{~s}, 50^{\circ} \mathrm{C} / 20 \mathrm{~s} \text {, and }\right. \\
\left.72^{\circ} \mathrm{C} / 1 \mathrm{~min}\right) ; 72^{\circ} \mathrm{C} / 7 \mathrm{~min}\end{array}$ & $\begin{array}{l}\text { Mihali } \\
\text { et al., } 2008\end{array}$ \\
\hline Microcystin & $\begin{array}{l}\text { mcyE-F2 } \\
\text { mcyE-R4 }\end{array}$ & mсyE (810) & $\begin{array}{l}\text { GAAATTTGTGTAGAAGGTGC } \\
\text { AATTCTAAAGCCCAAAGACG }\end{array}$ & $\begin{array}{l}95^{\circ} \mathrm{C} / 3 \mathrm{~min} ; 30 \text { cycles } \\
\left(94^{\circ} \mathrm{C} / 30 \mathrm{~s}, 56^{\circ} \mathrm{C} / 30 \mathrm{~s} \text {, and }\right. \\
\left.72^{\circ} \mathrm{C} / 1 \mathrm{~min}\right) ; 72^{\circ} \mathrm{C} / 10 \mathrm{~min}\end{array}$ & $\begin{array}{l}\text { Rantala } \\
\text { et al., } 2004\end{array}$ \\
\hline Saxitoxin & $\begin{array}{l}\text { OCT-F } \\
\text { OCT-R }\end{array}$ & sxtI (923) & $\begin{array}{l}\text { TGCCGTTTTGTGCTTAGATG } \\
\text { GGACGGAAGGACTCACGATA }\end{array}$ & $\begin{array}{l}94^{\circ} \mathrm{C} / 5 \mathrm{~min} ; 35 \text { cycles } \\
\left(94^{\circ} \mathrm{C} / 30 \mathrm{~s}, 61^{\circ} \mathrm{C} / 1 \mathrm{~min} \text {, and }\right. \\
\left.72^{\circ} \mathrm{C} / 1 \mathrm{~min}\right) ; 72^{\circ} \mathrm{C} / 7 \mathrm{~min}\end{array}$ & $\begin{array}{l}\text { Fiore et al., } \\
2010\end{array}$ \\
\hline Aeruginosin & $\begin{array}{l}\text { aerA_F } \\
\text { aerB_R }\end{array}$ & $\begin{array}{l}\text { aerA-aerB } \\
\text { intergenic } \\
\text { region (991) }\end{array}$ & $\begin{array}{l}\text { GATAGCACCCAGAACGGAAGC } \\
\text { CGTTAAACGGATGGTTAGAGC }\end{array}$ & $\begin{array}{l}95^{\circ} \mathrm{C} / 2 \mathrm{~min} ; 40 \text { cycles } \\
\left(95^{\circ} \mathrm{C} / 45 \mathrm{~s}, 50^{\circ} \mathrm{C} / 45 \mathrm{~s} \text {, and }\right. \\
\left.72^{\circ} \mathrm{C} / 1 \mathrm{~min}\right) ; 72^{\circ} \mathrm{C} / 7 \mathrm{~min}\end{array}$ & $\begin{array}{l}\text { Cadel-Six } \\
\text { et al., } 2008\end{array}$ \\
\hline Cyanopeptolin & $\begin{array}{l}\text { mcnC_F } \\
\text { mcnE_R }\end{array}$ & $\begin{array}{l}m c n C-m c n E \\
\text { intergenic } \\
\text { region (585) }\end{array}$ & $\begin{array}{l}\text { TAAGGATAATTTCTTTGAATTGGGAG } \\
\text { GGGAATAATCTCTAAATCAACAGC }\end{array}$ & $\begin{array}{l}95^{\circ} \mathrm{C} / 2 \mathrm{~min} ; 40 \text { cycles } \\
\left(95^{\circ} \mathrm{C} / 45 \mathrm{~s}, 50^{\circ} \mathrm{C} / 45 \mathrm{~s} \text {, and }\right. \\
\left.72^{\circ} \mathrm{C} / 1 \mathrm{~min}\right) ; 72^{\circ} \mathrm{C} / 7 \mathrm{~min}\end{array}$ & $\begin{array}{l}\text { Cadel-Six } \\
\text { et al., } 2008\end{array}$ \\
\hline
\end{tabular}

PCR reaction: $25 \mu \mathrm{L}$ reaction volume containing $10 \mathrm{ng}$ DNA, $0.25 \mu \mathrm{M}$ of each primer, $1.0 \mathrm{U}$ Taq DNA Polymerase, $200 \mu \mathrm{M} \mathrm{dNTPs}, 3 \mathrm{mM} \mathrm{MgCl}_{2}, 1 \times$ reaction buffer and Milli-Q water.

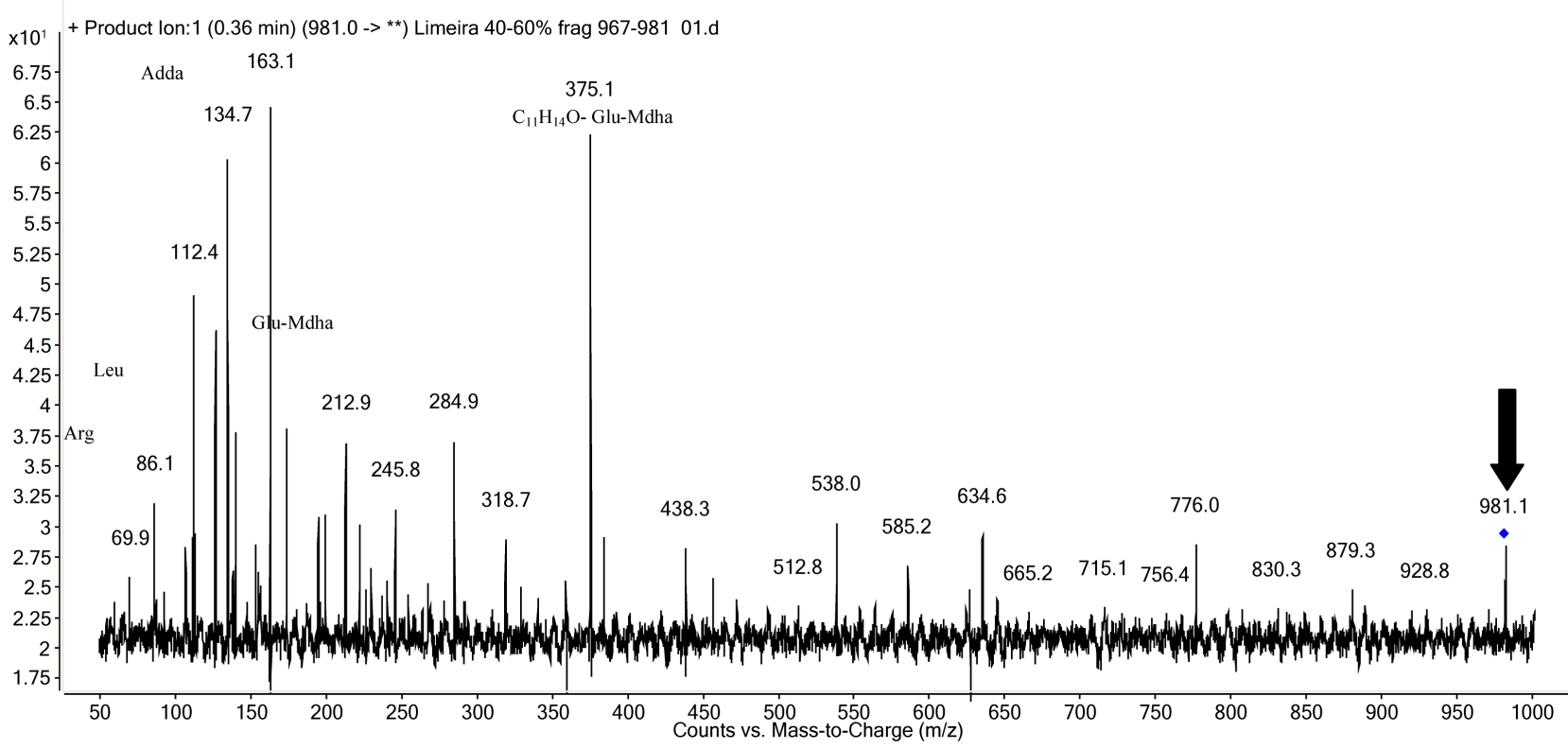

Figure S1. Spectra from LC-MS/MS analysis of microcystin-LR, m/z 981. 


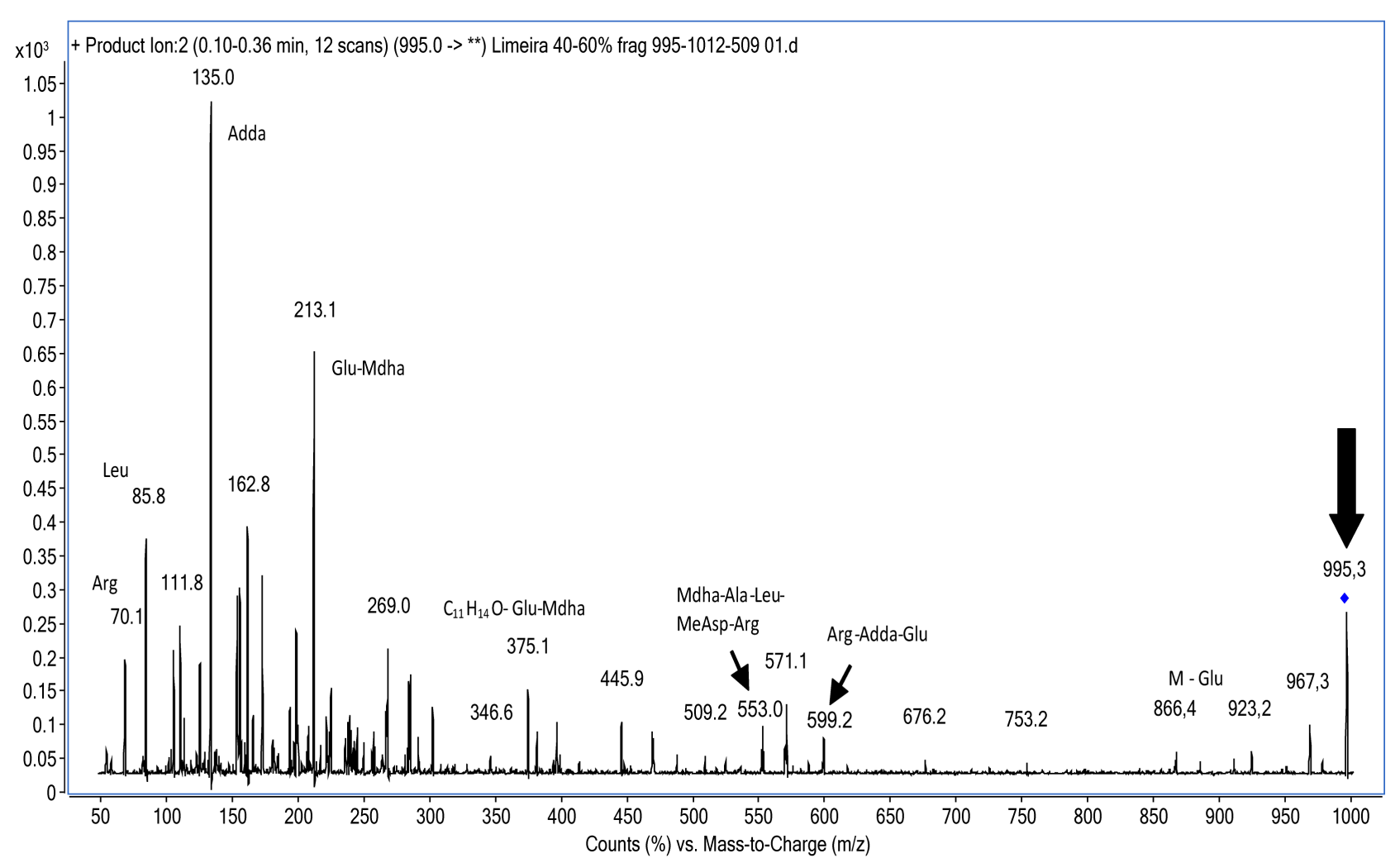

Figure S2. Spectra from LC-MS/MS analysis of microcystin-LR, m/z 995.

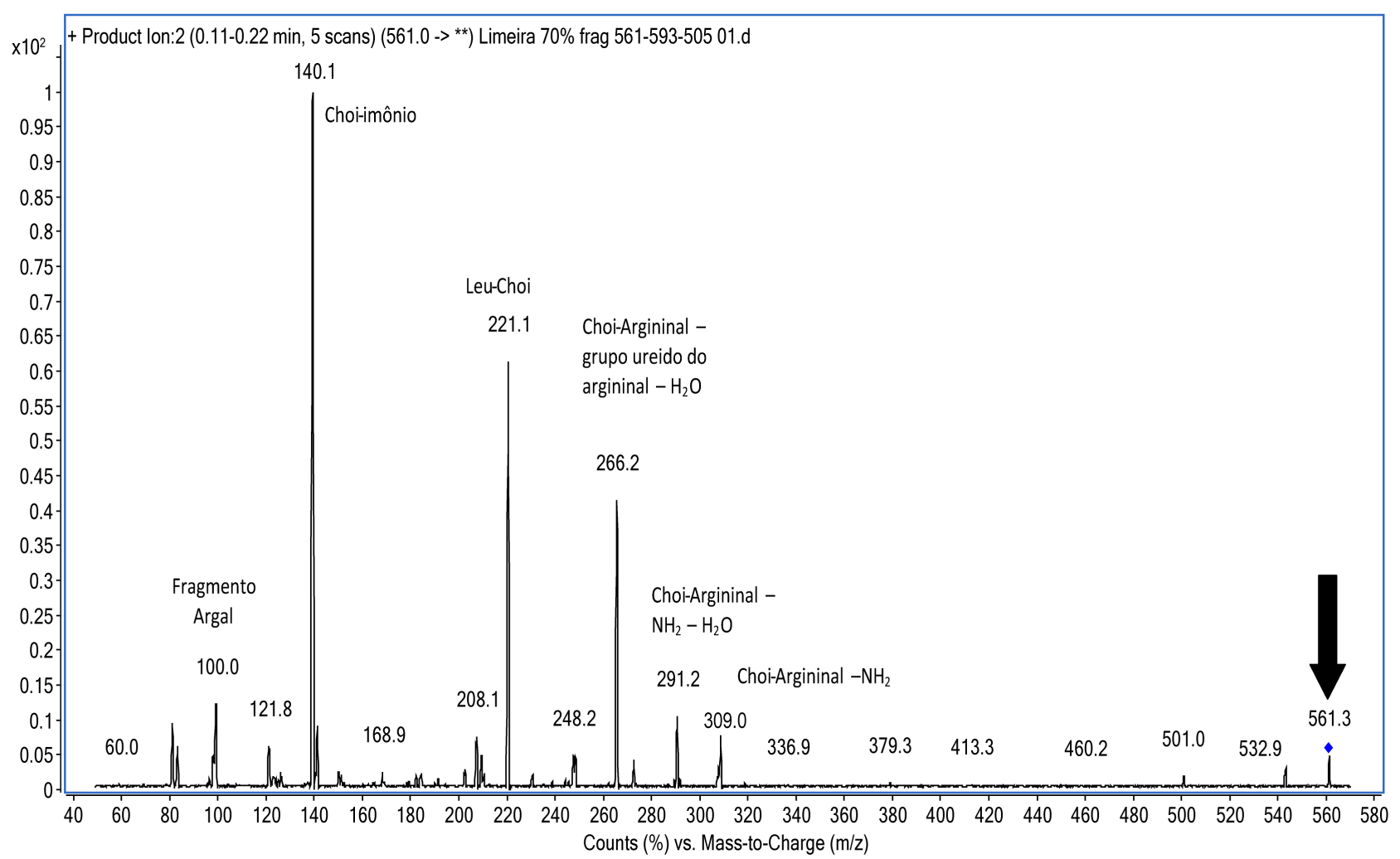

Figure S3. Spectra from LC-MS/MS analysis of aeruginosin, $m / z 561$. 


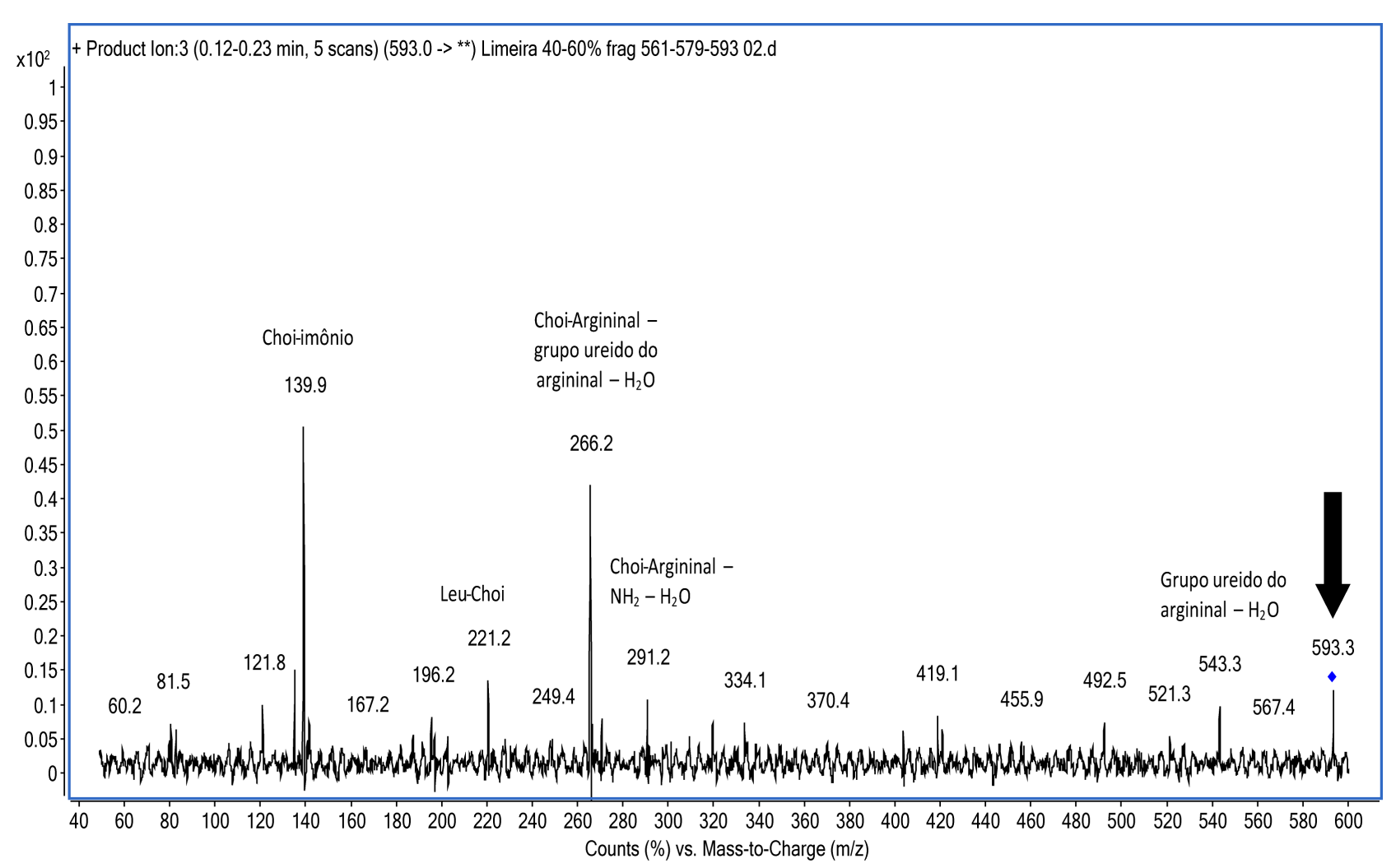

Figure S4. Spectra from LC-MS/MS analysis of aeruginosin, $m / z 593$.

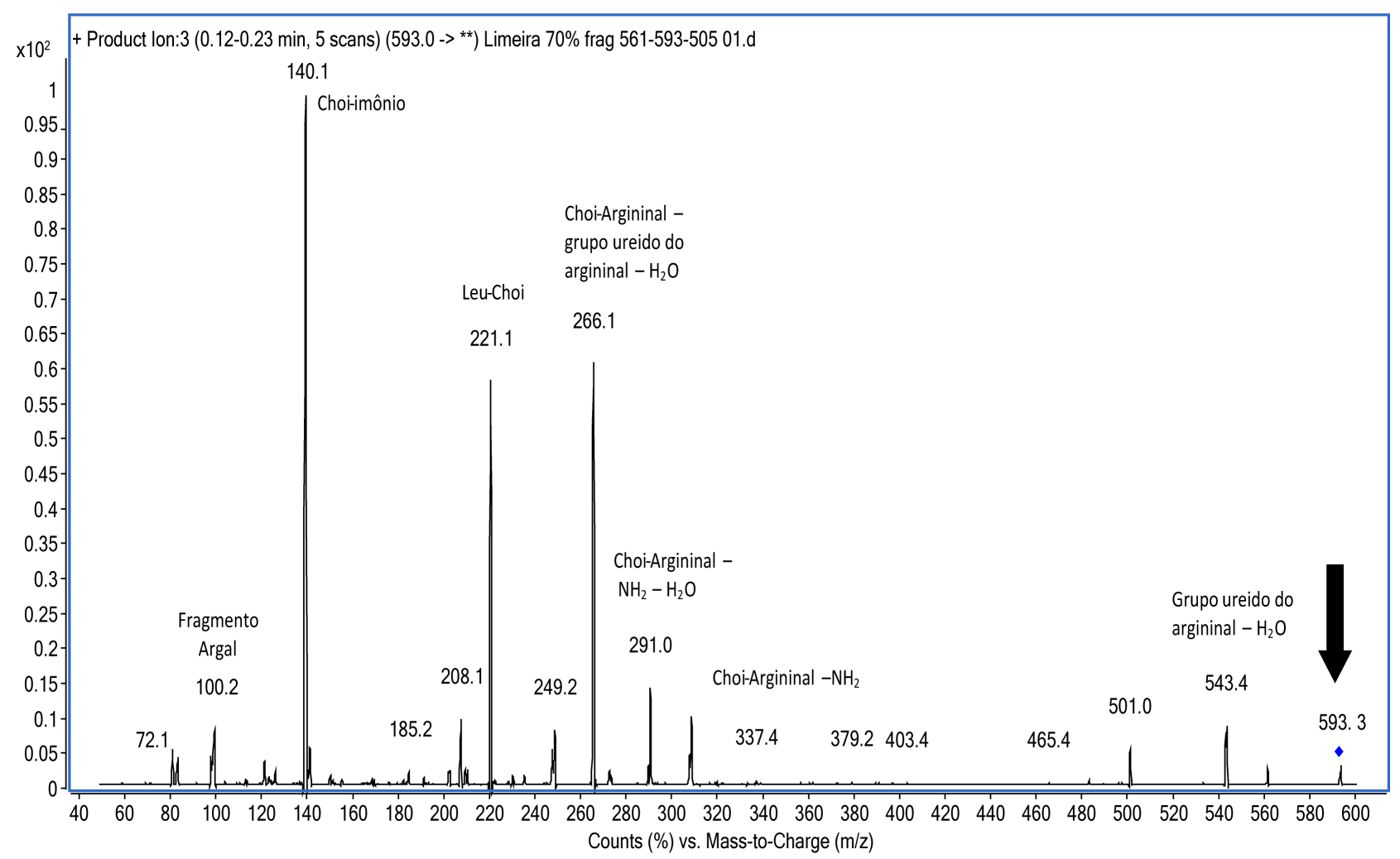

Figure S5. Spectra from LC-MS/MS analysis of aeruginosin, $m / z 593$. 


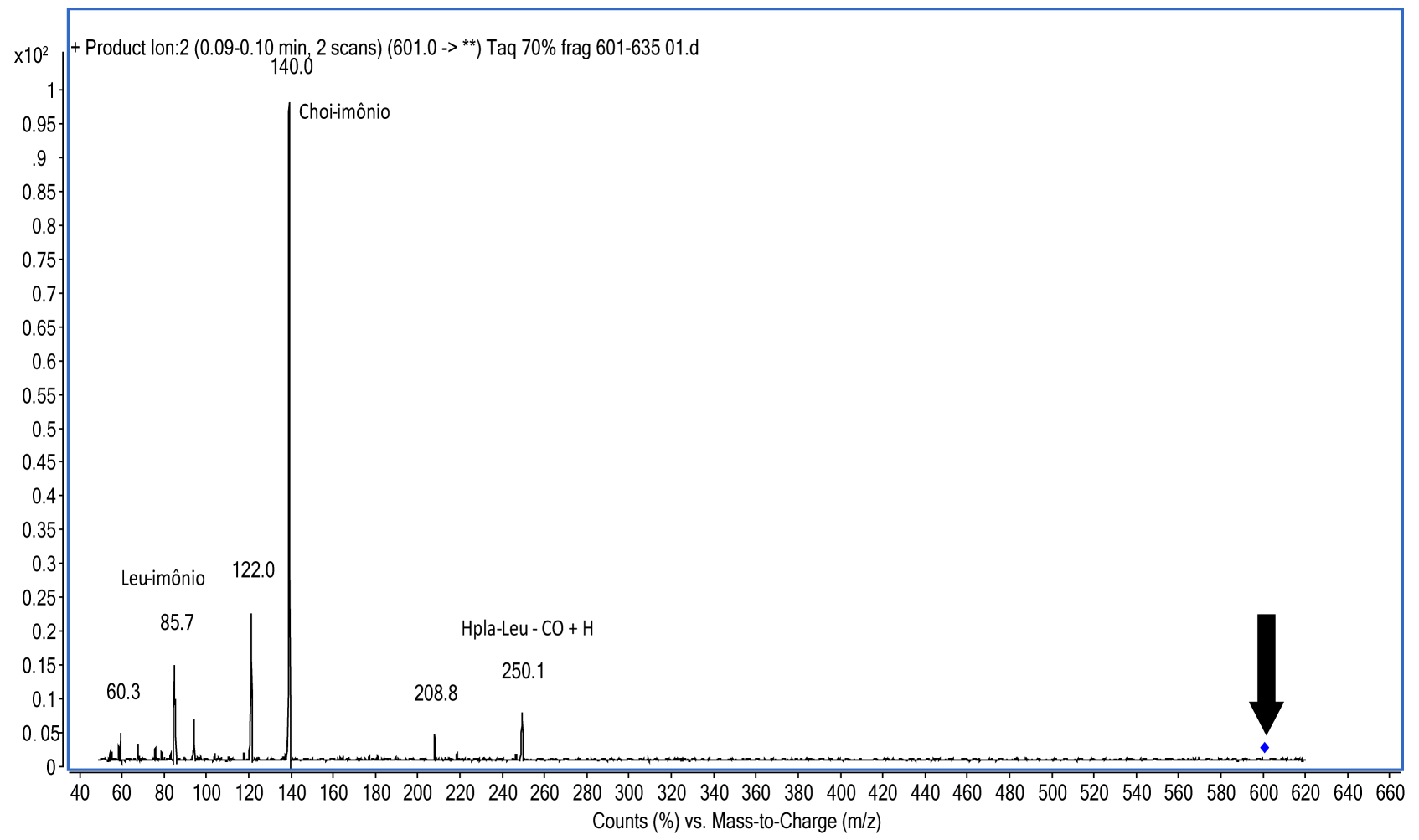

Figure S6. Spectra from LC-MS/MS analysis of aeruginosin, m/z 601.

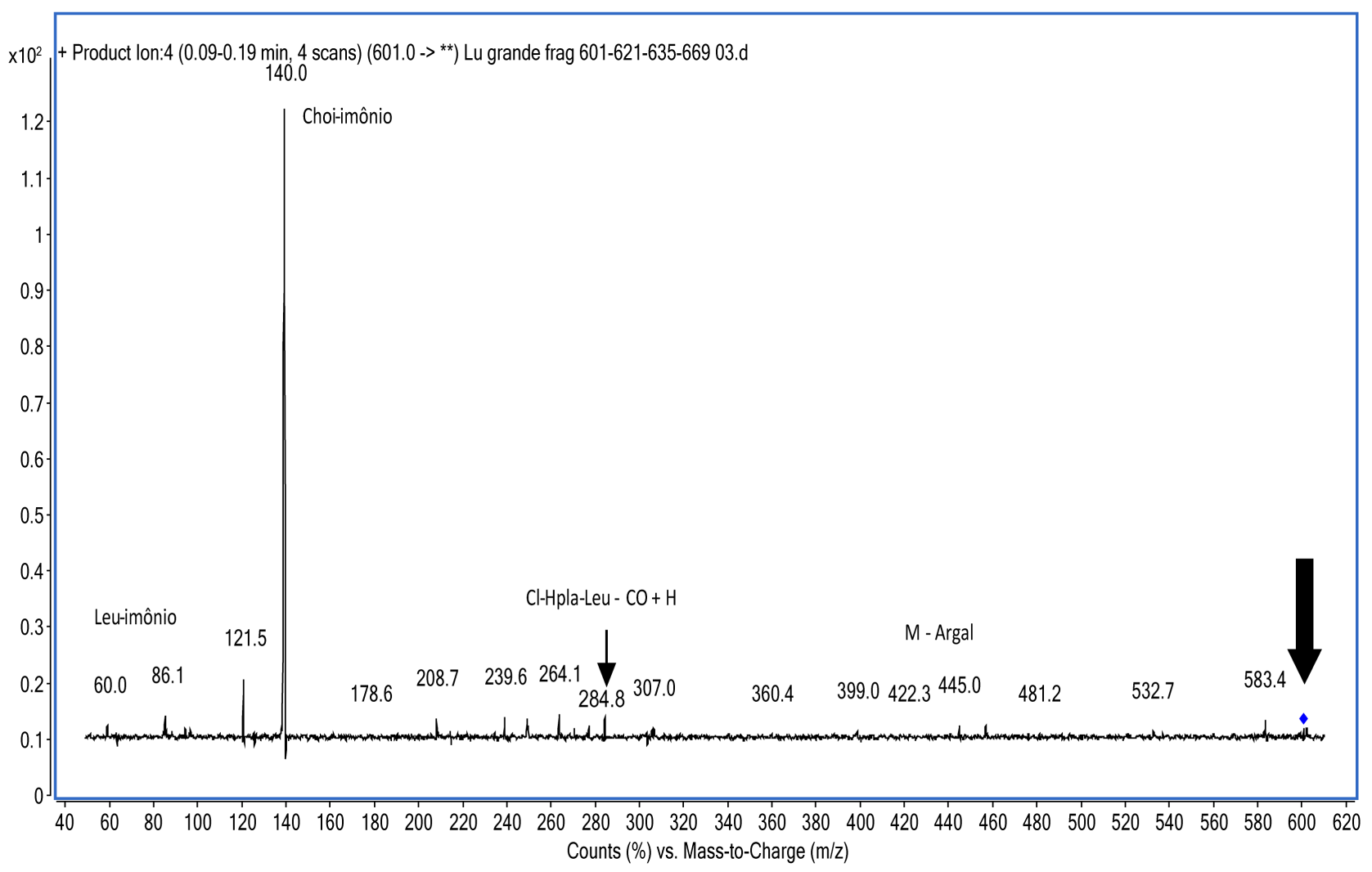

Figure S7. Spectra from LC-MS/MS analysis of aeruginosin, m/z 601. 


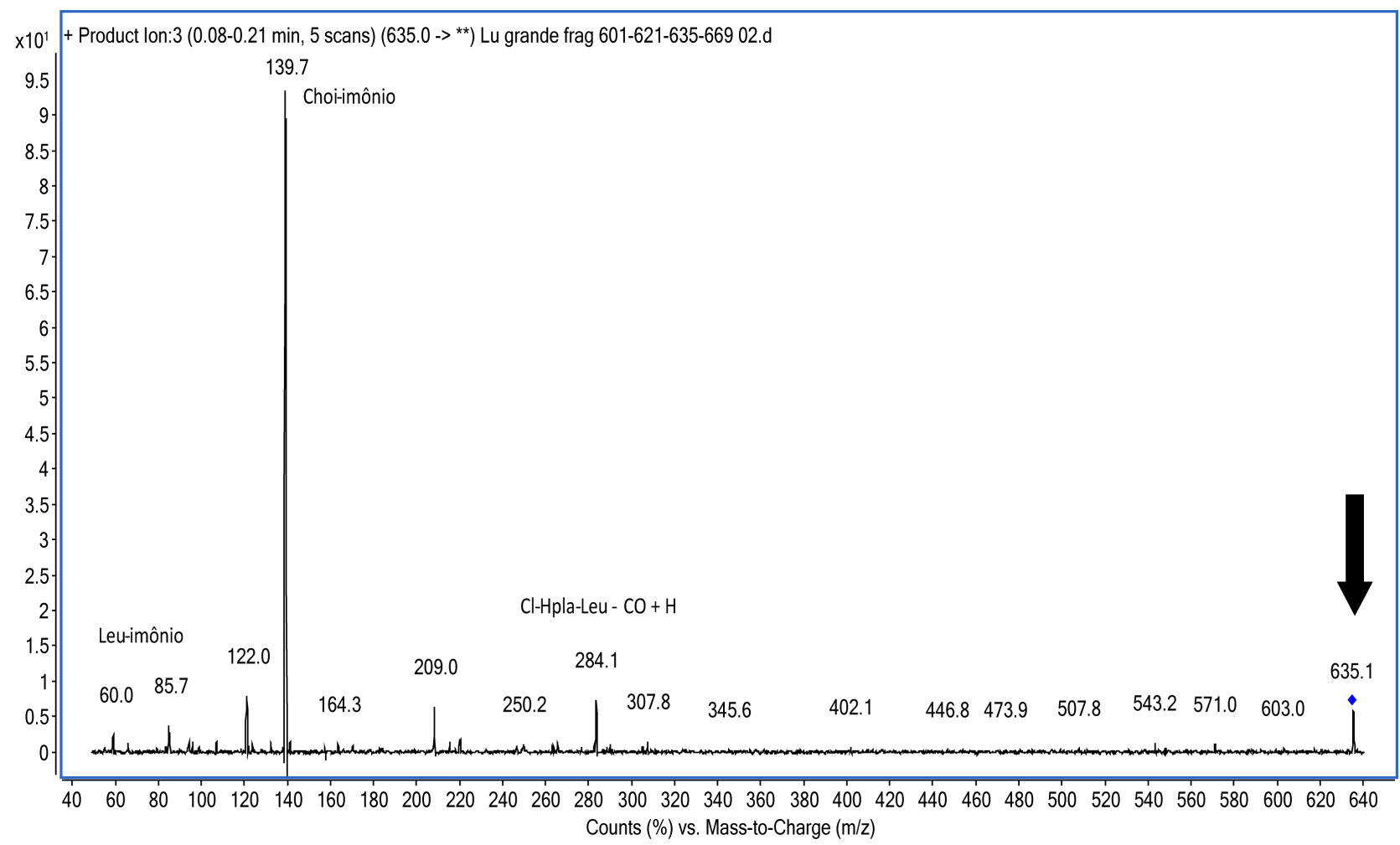

Figure S8. Spectra from LC-MS/MS analysis of aeruginosin, m/z 635 .

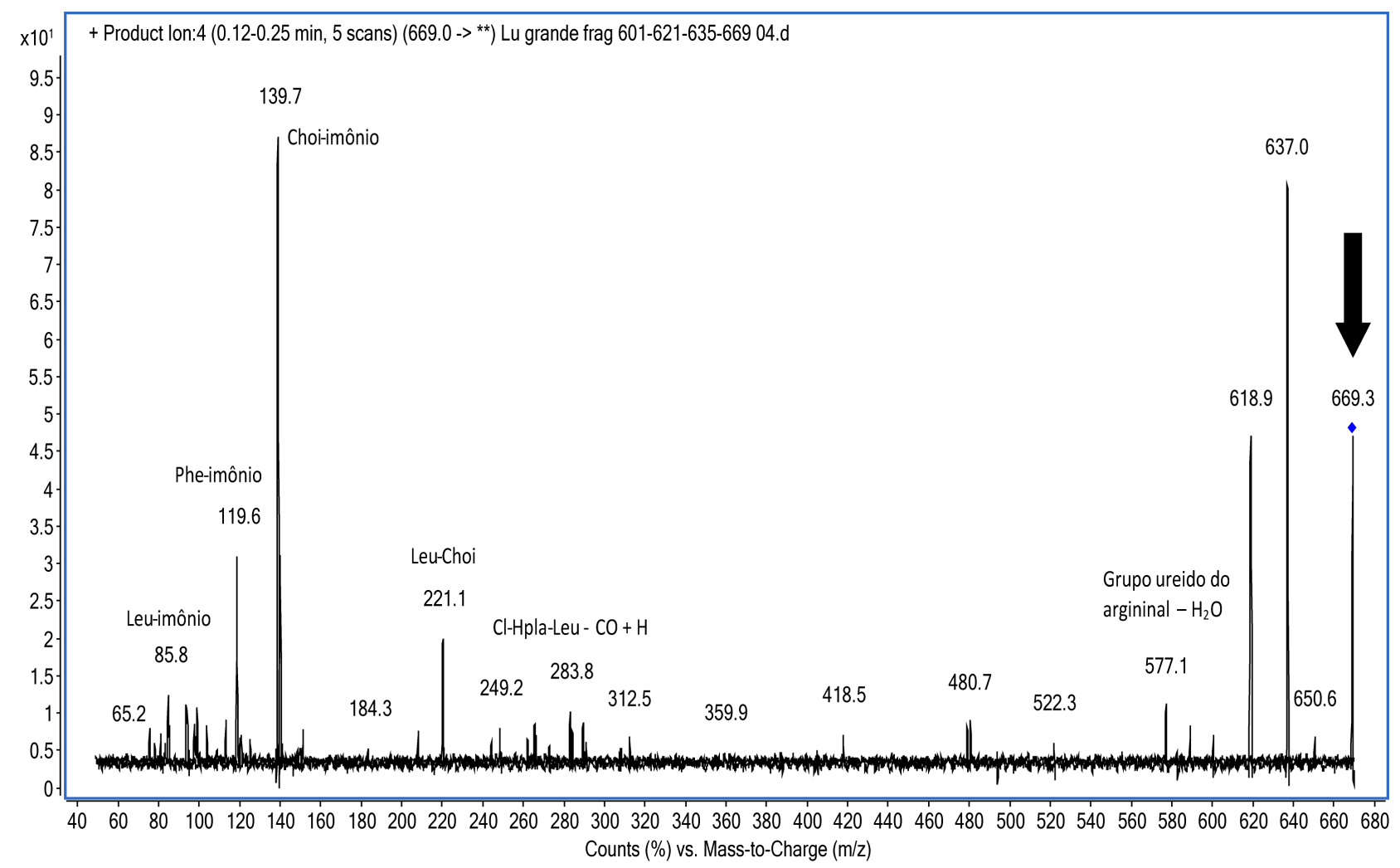

Figure S9. Spectra from LC-MS/MS analysis of aeruginosin, $m / z 669$. 


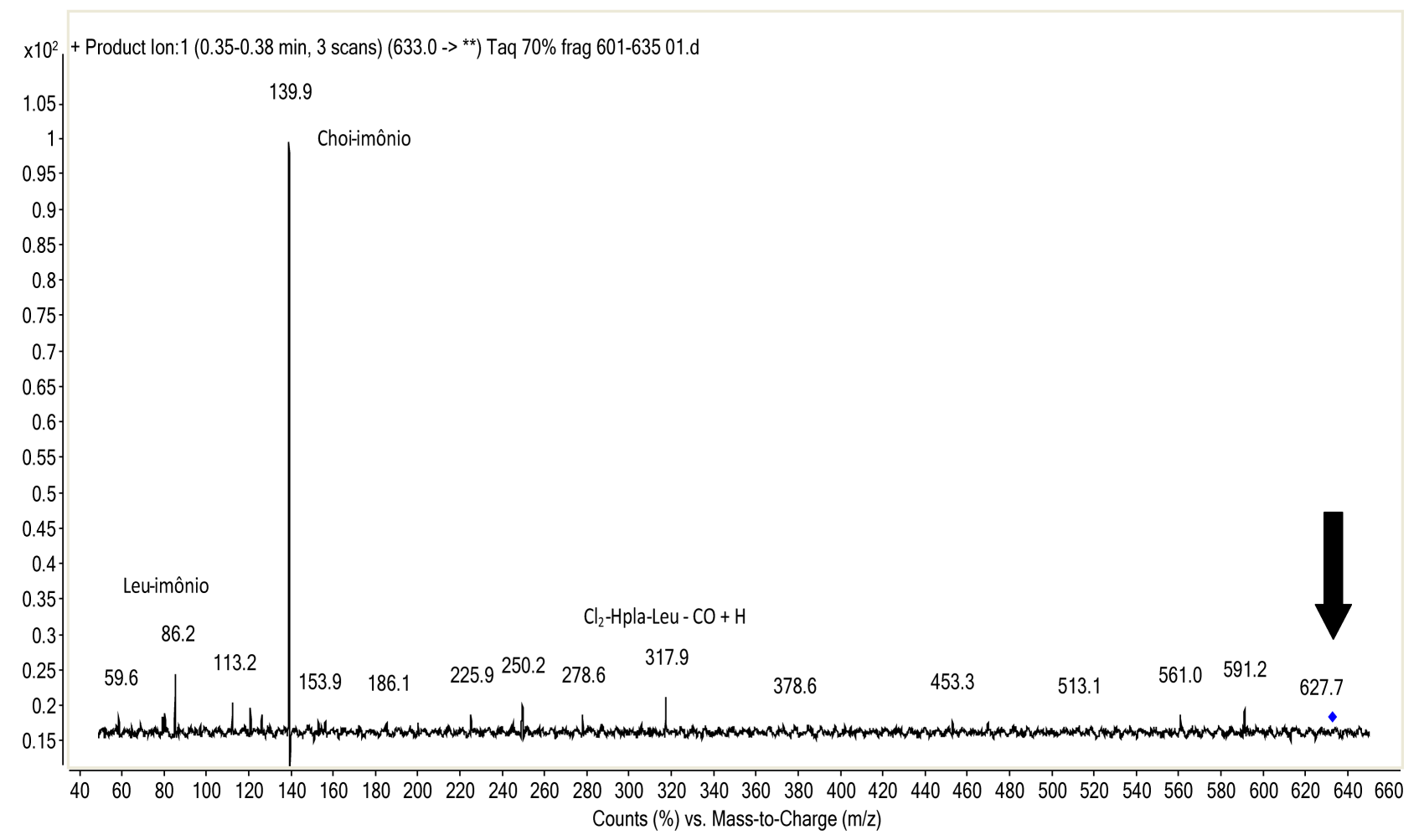

Figure S10. Spectra from LC-MS/MS analysis of aeruginosin, m/z 627.

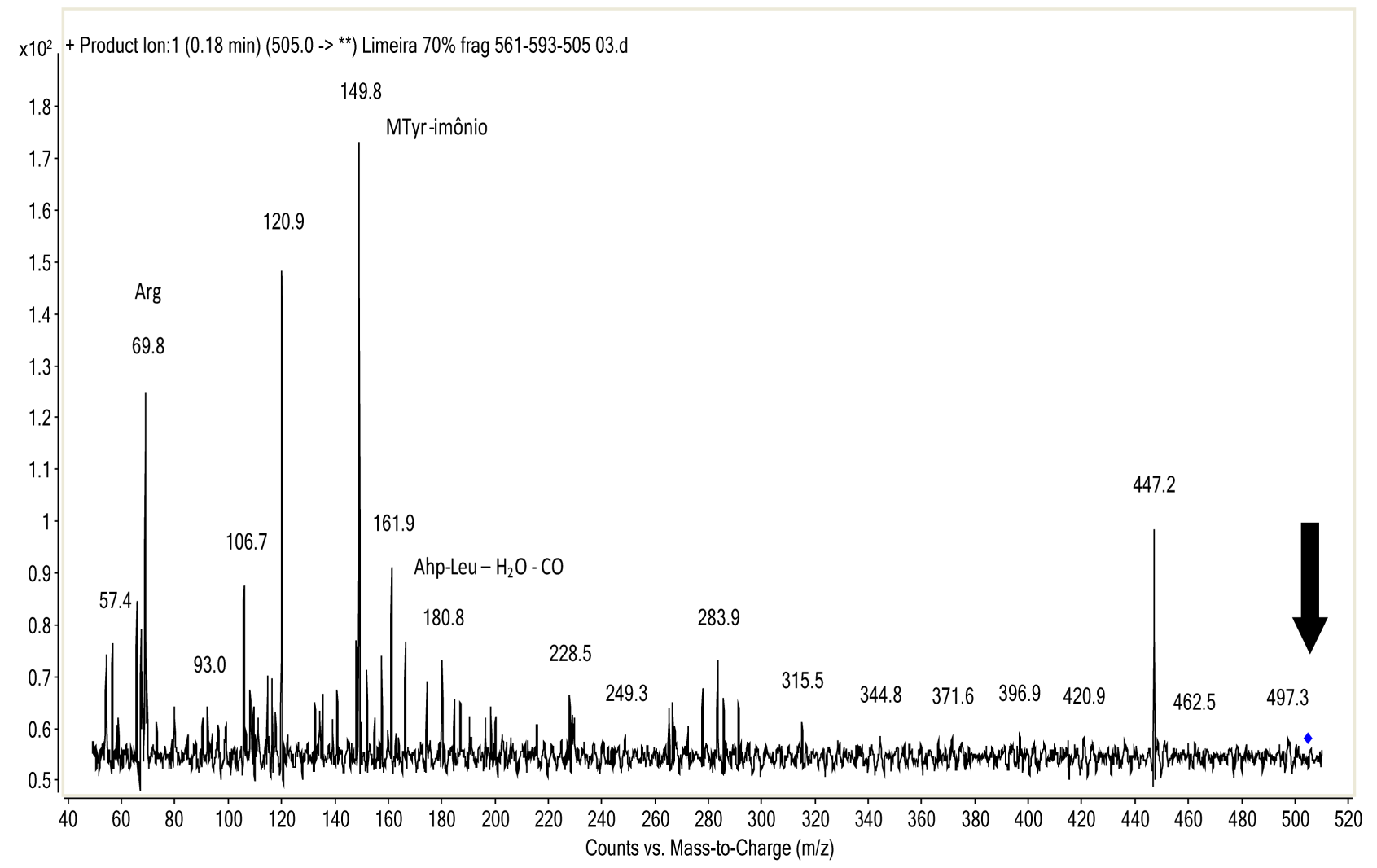

Figure S11. Spectra from LC-MS/MS analysis of cyanopeptolin, m/z 505. 


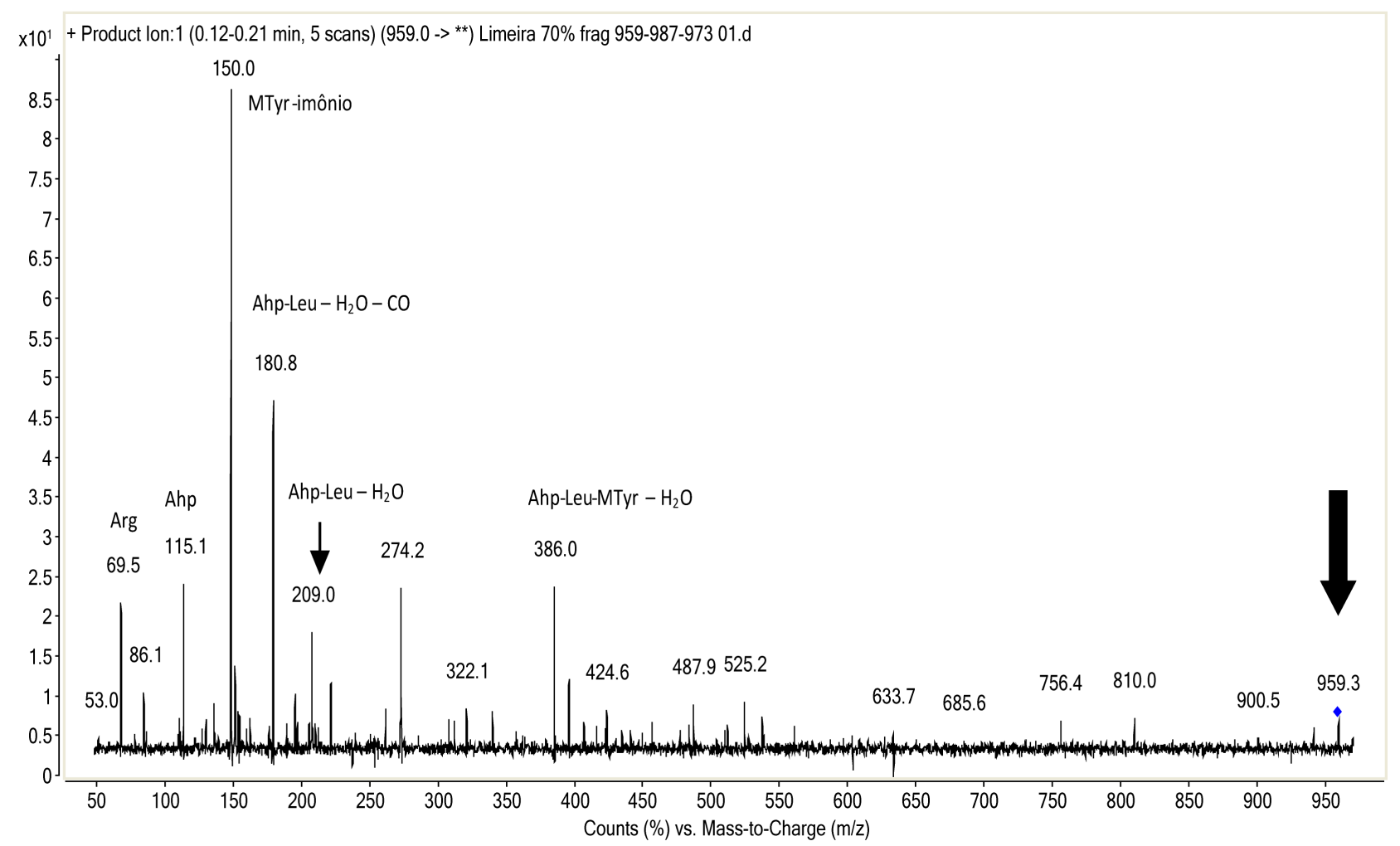

Figure S12. Spectra from LC-MS/MS analysis of cyanopeptolin, m/z 959.

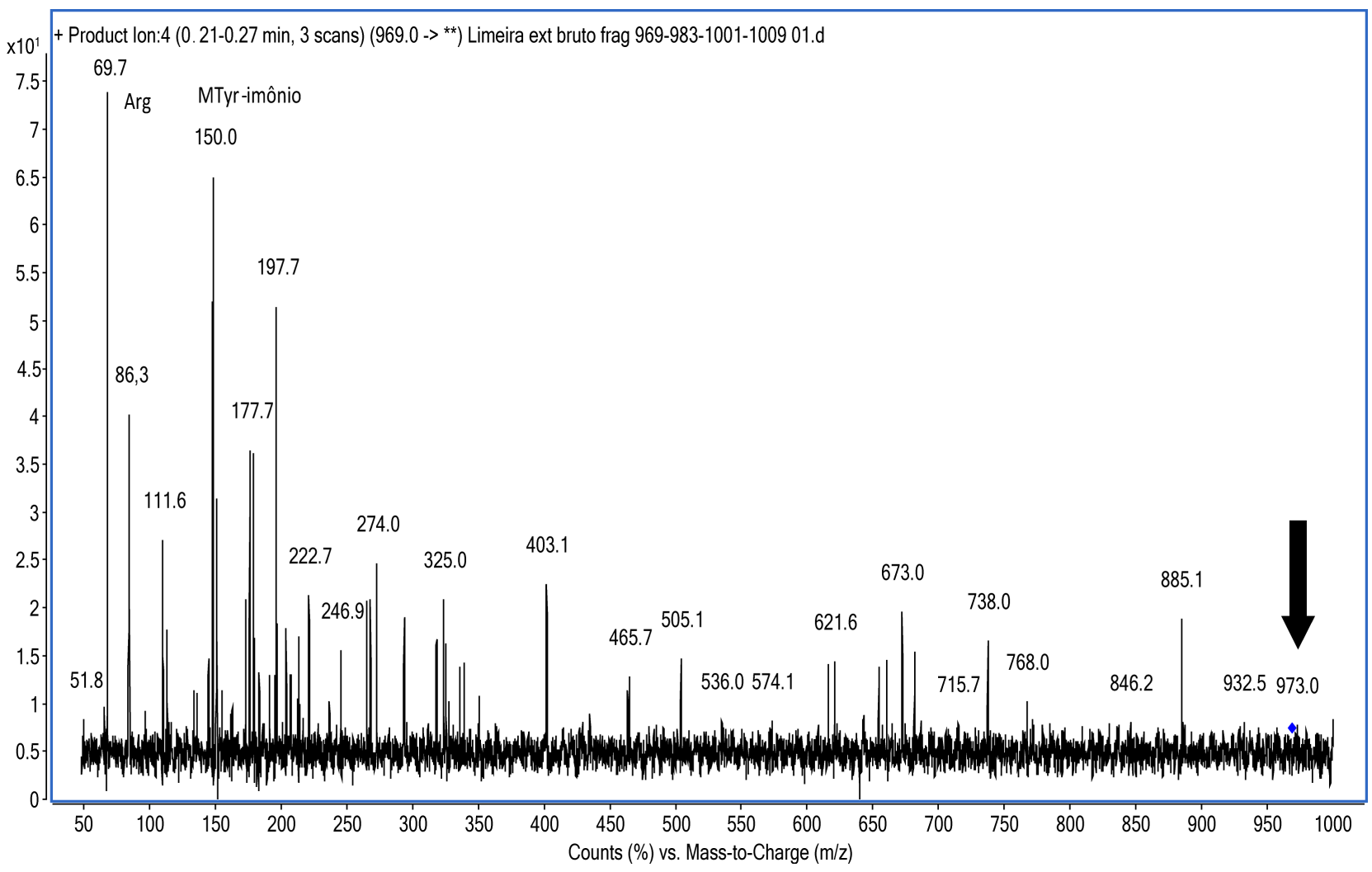

Figure S13. Spectra from LC-MS/MS analysis of cyanopeptolin, m/z 973. 


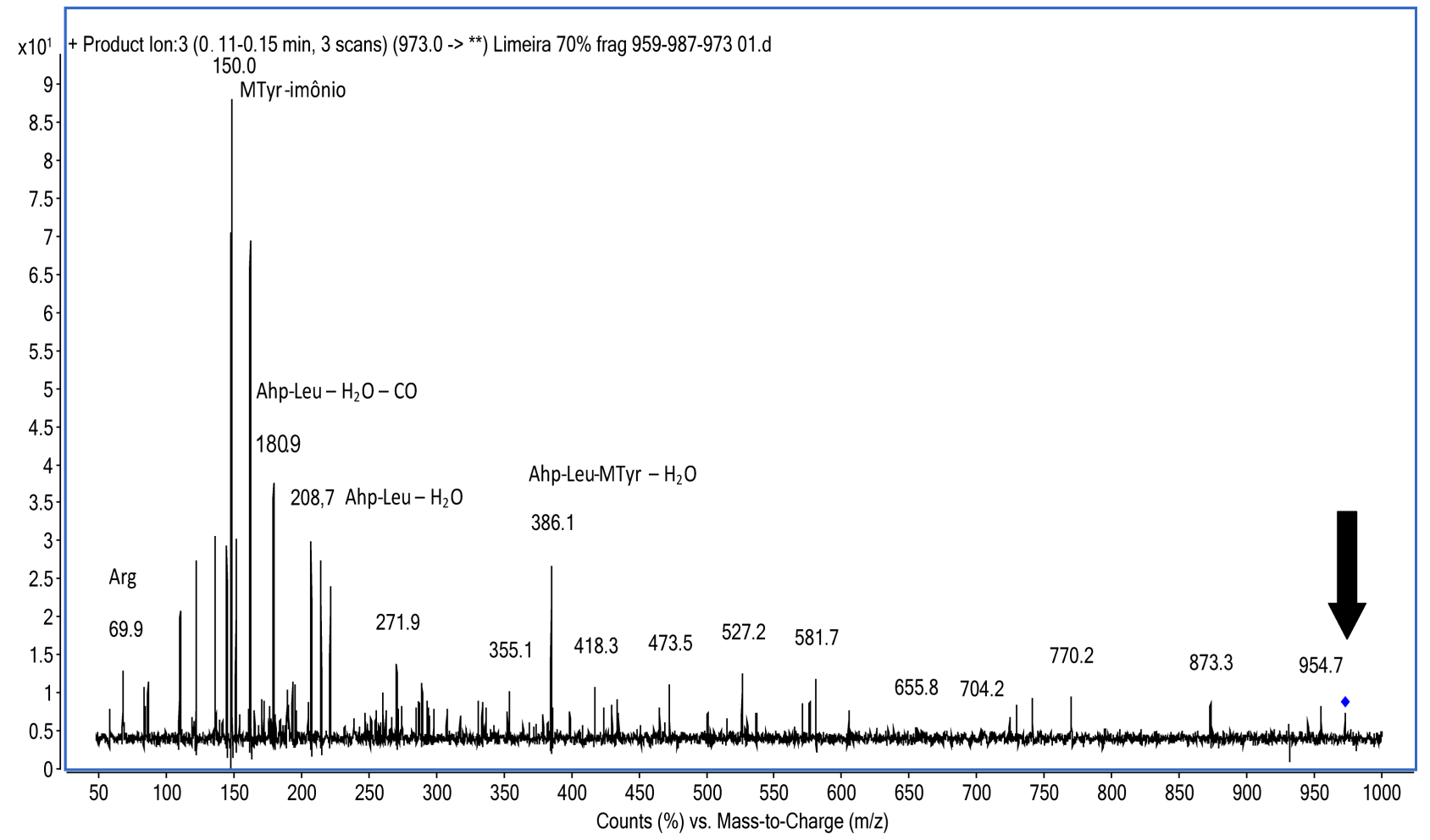

Figure S14. Spectra from LC-MS/MS analysis of cyanopeptolin, m/z 969.

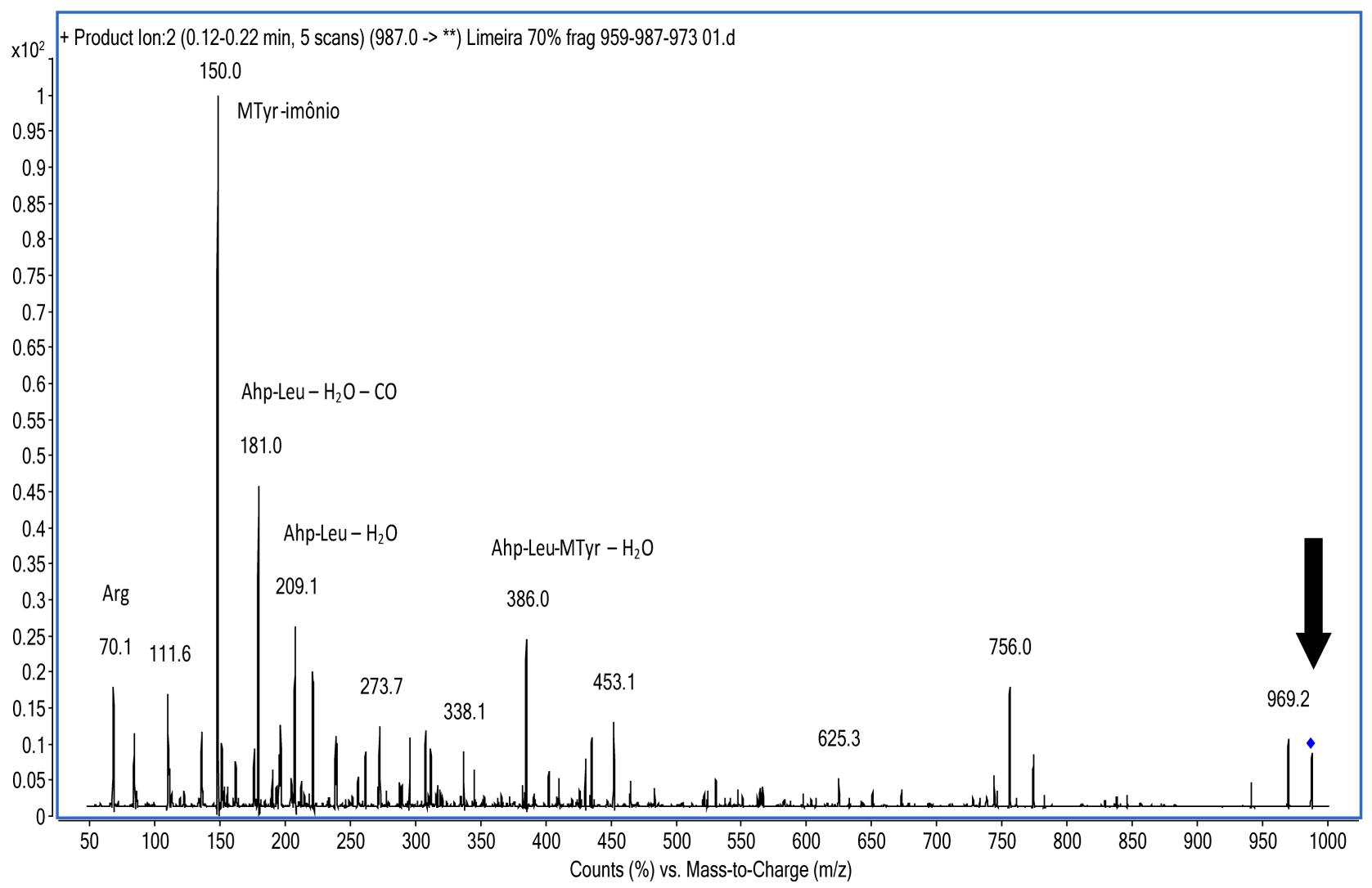

Figure S15. Spectra from LC-MS/MS analysis of cyanopeptolin, m/z 987. 
Scientific Research Publishing (SCIRP) is one of the largest Open Access journal publishers. It is currently publishing more than 200 open access, online, peer-reviewed journals covering a wide range of academic disciplines. SCIRP serves the worldwide academic communities and contributes to the progress and application of science with its publication.

Other selected journals from SCIRP are listed as below. Submit your manuscript to us via either submit@scirp.org or Online Submission Portal.
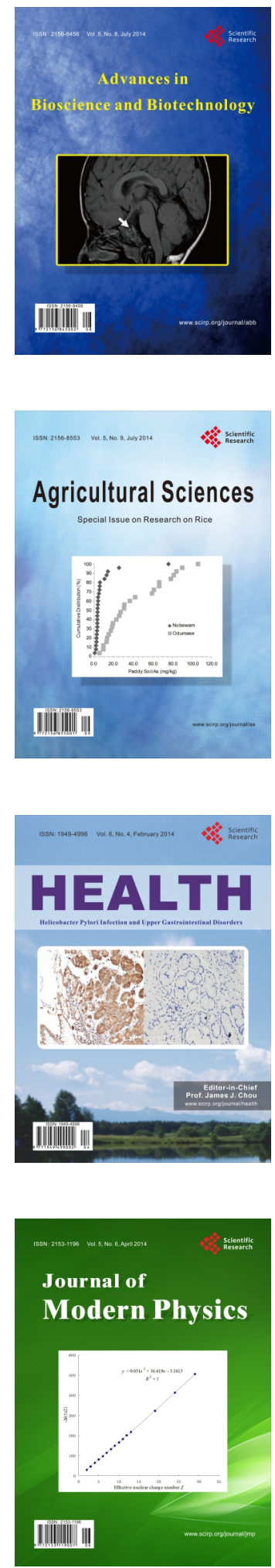
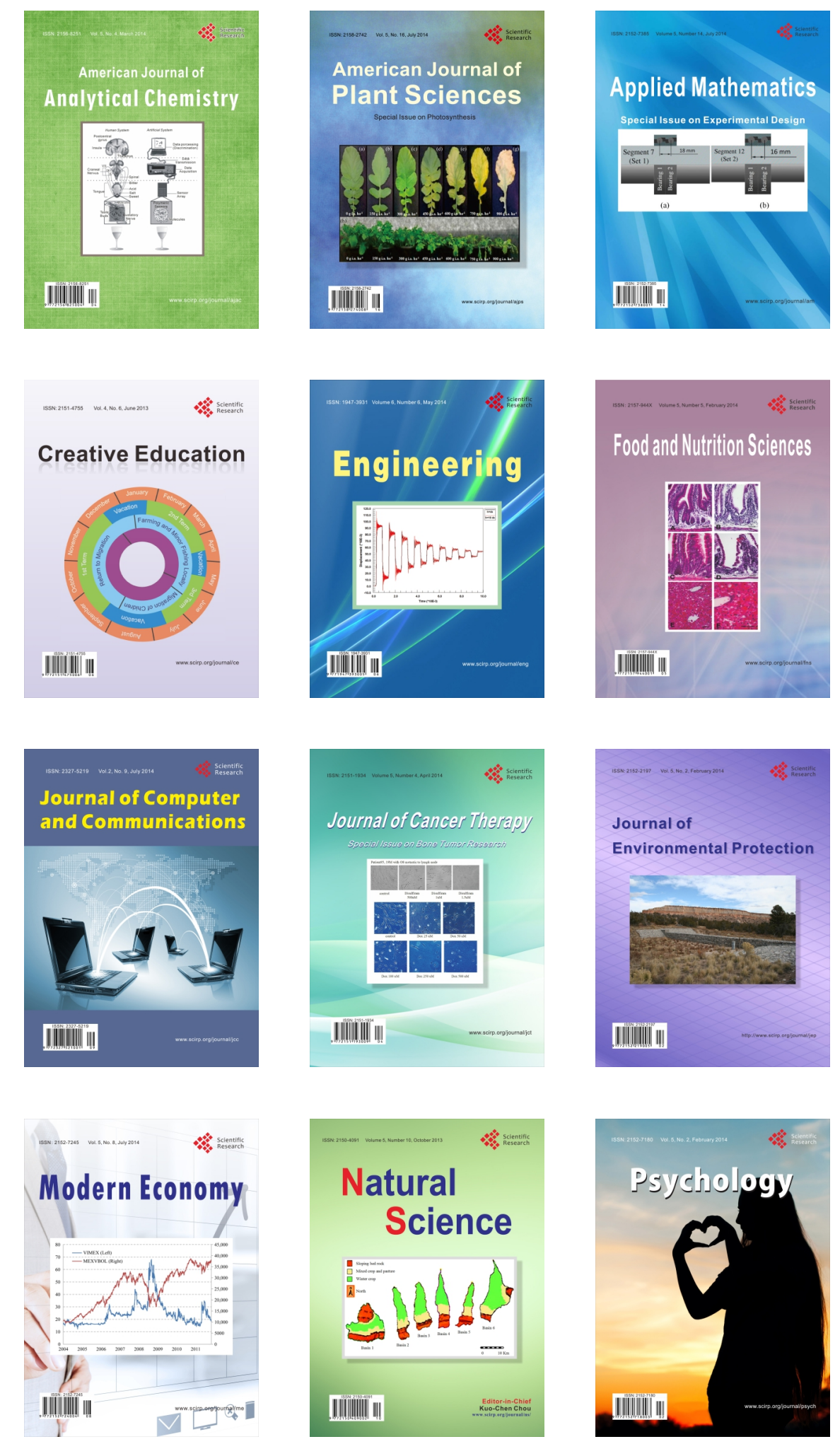